\title{
Análisis arqueológico de la torre-puerta de la alcazaba de Guadix (Granada)*
}

\section{Archaeological analysis of Guadix alcazaba's gate tower (Granada)}

\author{
Jorge Rouco Collazo ${ }^{1}$, José M. a Martín Civantos², José Antonio Benavides López ${ }^{3}$ \\ Universidad de Granada
}

\section{RESUMEN}

Este artículo tiene como objetivo realizar el análisis de la secuencia constructiva de la torre-puerta de la alcazaba medieval de Guadix (Granada). Para ello, se efectuó un levantamiento tridimensional de la estructura mediante fotogrametría, una lectura estratigráfica de paramentos e n p rofundidad y una caracterización de técnicas constructivas. Esto nos ha permitido comprobar que la torre-puerta tiene una compleja evolución histórica, lo que hace posible comprender mejor la historia de la alcazaba accitana desde su erección en época zirí hasta la actualidad, con importantes transformaciones en época almohade, nazarí, castellana y contemporánea.

Palabras clave: al-Ándalus; lectura estratigráfica; técnicas constructivas; fotogrametría; secuencia constructiva.

\begin{abstract}
The aim of this paper is to analyze the building sequence of the gate tower of the medieval alcazaba of Guadix (Granada). To achieve this, we have made a tridimensional mapping of the structure through photogrammetry, an in deep stratigraphic analysis of the walls and a characterization of building techniques. These have allowed us to prove that the gate tower has a complex historic evolution, that makes possible to get a better understanding of the history of the alcazaba, from its construction in Zirid period to current times, with major transformations in Almohad, Nasrid, Castilian and Contemporary periods.
\end{abstract}

Key words: al-Ándalus; stratigraphic analysis; building techniques; photogrammetry; building sequence.

Recibido: 04-01-2018. Aceptado: 14-02-2018. Publicado online: 24-07-2018

\section{Cómo citar este artículo / Citation}

Rouco Collazo, J., Martín Civantos, J. M. a y Benavides López, J. A. 2018: "Análisis arqueológico de la torre-puerta de la alcazaba de Guadix (Granada)", Arqueología de la Arquitectura, 15: e072. https://doi.org/10.3989/arq.arqt.2018.010

Copyright: (c) 2018 CSIC. Este es un artículo de acceso abierto distribuido bajo los términos de la licencia de uso y distribución Creative Commons Reconocimiento 4.0 Internacional (CC BY 4.0).

\footnotetext{
* El presente trabajo es resultado del proyecto I+D "De Acci a Guadix. Reinterpretando el pasado de una ciudad histórica para proteger su patrimonio y contribuir a su desarrollo (Granada)" (HAR 2013-48423-P), financiado por el Ministerio de Economía y Competitividad. Parte ha sido financiado también por la Universidad de Granada mediante una beca de Iniciación a la Investigación para Máster otorgada a J. Rouco por el proyecto "Técnicas de digitalización del patrimonio arqueológico construido de Guadix". Todas las figuras han sido realizadas por los autores excepto el caso de las Figs. 3 y 4 , en las que se indica su correspondiente autoría.

jbenavid@ugr.es / ORCID iD http://orcid.org/0000-0002-2321-113X
} 


\section{INTRODUCCIÓN}

El objeto del presente artículo es presentar los resultados del análisis de la secuencia histórico-constructiva de la torre-puerta de la alcazaba de Guadix (Granada). El estudio parte inicialmente del proyecto de parque arqueológico que debería haberse desarrollado en este monumento desde 2009, pero que quedó paralizado tras la llegada de la crisis y la falta de financiación. A partir de ahí nos planteamos llevar a cabo una investigación más ambiciosa sobre la ciudad que contribuyera también a la conservación de su importante patrimonio y al desarrollo social y económico de la misma. El contexto no ha sido el más apropiado en muchos aspectos, pero estamos convencidos de que una localidad con la excepcional riqueza arqueológica, arquitectónica y artística de Guadix debería servir de modelo de buenas prácticas en el registro, documentación y gestión del patrimonio arquitectónico y arqueológico ${ }^{4}$.

Un buen ejemplo de esta riqueza patrimonial es su alcazaba, que se encuentra en la zona alta de la ciudad, en la parte sur de la antigua cerca urbana andalusí, a una altura de $952 \mathrm{~m}$ sobre el nivel del mar (Fig. 1). Presenta una planta rectangular con el flanco meridional redondeado. Está compuesta por tres recintos (Fig. 2): el primero, el interior, se sitúa en la parte más elevada del cerro. Conserva cuatro torres y los lienzos que las unen, incluida la

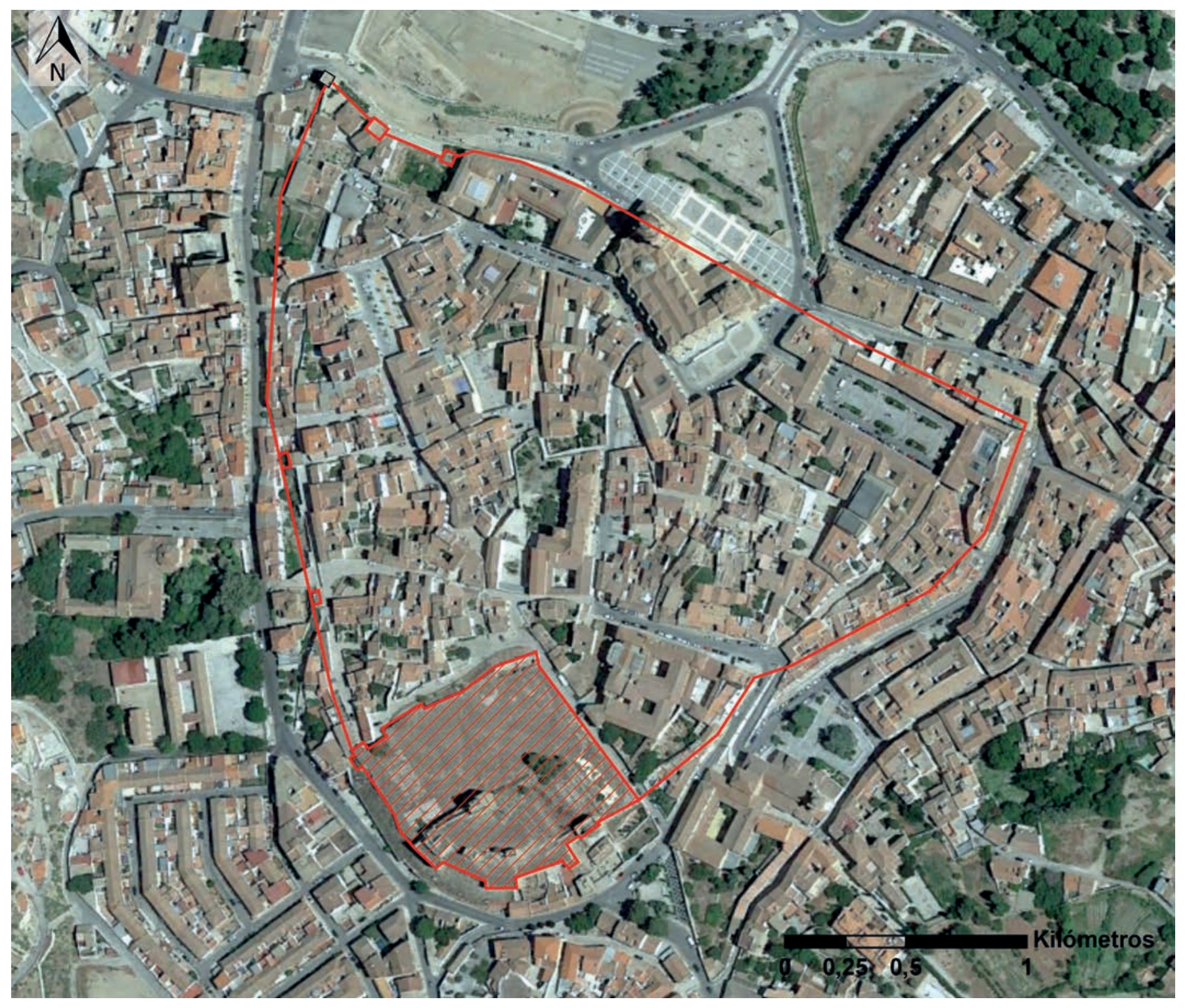

Figura 1. Trazado de la muralla andalusí de Guadix y ubicación de la alcazaba. 
conocida como torre del homenaje, ubicada en el extremo septentrional de este perímetro. Es la más alta de todo el conjunto, con una altura de $21 \mathrm{~m}$. La zona noreste de este conjunto de la fortificación se encuentra totalmente modificada por la creación de una plataforma aterrazada en el siglo pasado, no quedando en superficie ningún resto de época medieval.

El segundo recinto se encuentra en el extremo meridional del complejo. Se trata de una barbacana que refuerza esta cara de la alcazaba, que en época andalusí se orientaba hacia el exterior de la cerca de la medina. Se compone de tres grandes torres abiertas hacia el interior, rellenadas por tierra hasta nivel del adarve, al igual que los paños de muralla que las unen.

El tercer perímetro es el exterior, que engloba a los dos recintos interiores por el oeste, el norte y el este, por lo que presenta una forma de L. Este recinto se encuentra muy modificado, aunque todavía se pueden observar hasta cinco torres embutidas en los lienzos (Martín Civantos y Raya 2009: 289-294). Aquí se sitúan los dos accesos a la alcazaba: el que comunicaba con la medina en la zona norte y la torre-puerta justo al este del primer recinto, que trataremos con más detalle. Esta estructura sufrió un derrumbe parcial en el año 2005 como consecuencia de un terremoto, realizándose de inmediato una intervención de consolidación provisional con una estructura de hierro a la espera de una restauración definitiva, que todavía no se ha producido. Si bien como veremos no se trata realmente de una torre-puerta, mantendremos esta denominación popular para evitar malentendidos.

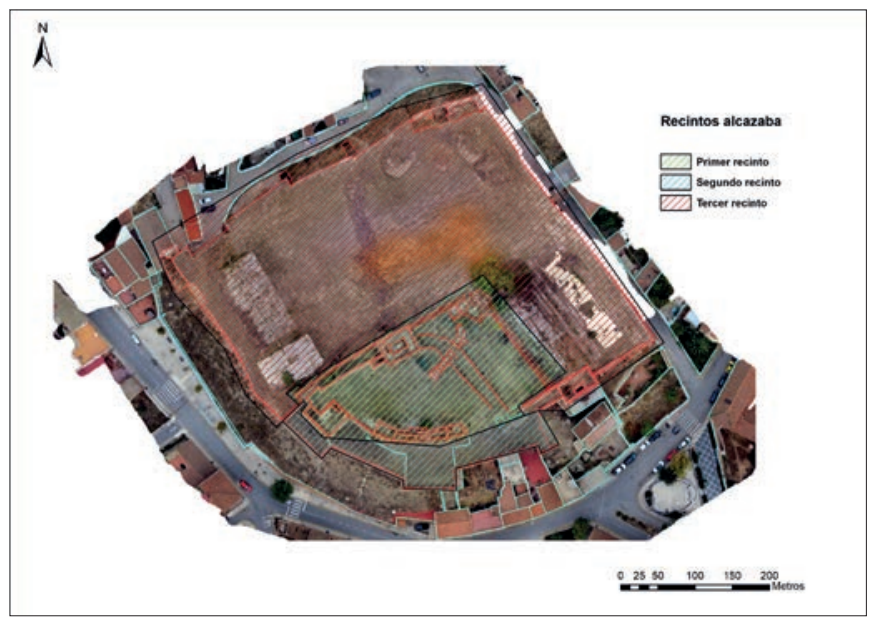

Figura 2. Recintos de la alcazaba de Guadix.

Nuestros conocimientos sobre la evolución de Guadix en época medieval se ven limitados por la exigua información disponible en las fuentes escritas y la escasez de las intervenciones arqueológicas urbanas realizadas, con gran disparidad metodológica (Ramírez 2017). El poblamiento en el solar de la ciudad se remonta a la instalación de la colonia romana de Iulia Gemella Acci sobre el antiguo oppidum ibérico. El enclave alcanza cierta importancia regional por su favorable ubicación geográfica en la encrucijada de caminos entre el valle del Guadalquivir y el Levante y Sierra Morena y la costa mediterránea a través de los pasos de montaña de Sierra Nevada (Martín Civantos 2010b). A partir del siglo III d.C. se produce un declive en la vida urbana pese a la instalación de una sede episcopal en el siglo IV. Las menciones en la documentación para época tardoantigua se reducen enormemente y existe también un gran vacío en los niveles arqueológicos de los siglos $\mathrm{V}$ y VI que muestran este imparable proceso (Martín Civantos 2010b; Salvador 1998).

La implantación del nuevo poder tras la conquista musulmana resulta así mismo incierto. La toma de la ciudad no es mencionada en las crónicas de la conquista, lo que refuerza la teoría de la decadencia cívica. La llegada de nuevos pobladores no parece revertir este proceso, puesto que, aunque se documente poblamiento en Guadix entre los siglos VIII y X, su intensidad no es suficiente como para considerarlo como urbano. Según Ibn Hazm y al Udri, en la zona se instalan principalmente tribus yemeníes (Sánchez 1976; Sarr 2011).

Guadix comienza a recuperar peso urbano como aglutinador del entorno a partir de la época zirí, momento en el que se la dotará con una alcazaba por su ubicación estratégica para esta dinastía, como trataremos con más profundidad posteriormente. La ciudad se convierte en la cabeza militar, fiscal y judicial de un distrito que comprende la Hoya de Guadix y la comarca del Zenete, estatus que conservará hasta la conquista cristiana (Martín Civantos 2007: 584 y 688). La medina continuará creciendo en época de los imperios norteafricanos, alcanzando su culmen en época nazarí, siendo un importante foco comercial en la zona y contando con varios arrabales fortificados.

El conocimiento que se tiene de la alcazaba accitana por las fuentes históricas es, al igual que para el resto de la medina, muy limitado. Teóricamente, la primera mención a una fortificación la encontramos con la noticia de que en la ciudad de Guadix se instala la familia yemení de los Banu Sami en el siglo IX (Ibn Hayyan 1954: 341). Esta edificaría una fortaleza de la que no queda constancia material y que plantea problemas para su ubicación. 
Según la propuesta de Malpica (2009: 115), a partir de aquí empezaría a conformarse la medina de Guadix, pero no tenemos actualmente ninguna evidencia en este sentido. Será en el siglo XI cuando aparezca como una fortaleza plenamente conformada. El último gobernante zirí menciona en sus memorias la existencia de una alcazaba en la ciudad, en el contexto de un enfrentamiento del rey granadino Badis con la vecina taifa de Almería. Recuperarla de manos almerienses supuso que "los gastos del asedio agotaron seis salas del tesoro" (Abd Allah 2005: 135). Pese a lo exagerado de la cifra, sirve de indicio para considerar que la fortificación accitana tendría ya una entidad considerable.

Lo mismo podría decirse cuando entre 1125-1126 la ciudad es asediada por las tropas de Alfonso I el Batallador en varias ocasiones, llegando las fuentes a afirmar que estuvo en la comarca durante un mes entero (Huici 1951: 109 y ss.; Ibn al Jatib 1976: vol. I, 109-119; Ubieto 1955: 127-128). Pero será a partir del siglo XIII con la dinastía nazarí, cuando Guadix aparezca como un núcleo muy vinculado al nuevo poder (Sarr y Mattei 2011). Los monarcas nazaríes se intitularán alcaides de la ciudad, y Guadix servirá a menudo como refugio para sultanes huidos de la capital a causa de conjuras en su contra, como Muhammad V o Nasr. Pero también se convierte en bastión de rebeldes contra la autoridad de la Alhambra, como el Zagal, último gobernante musulmán de Guadix antes de la capitulación de 1489. Por este motivo, Ibn al Jatib refiere que "su fortaleza pertenece a la gente de la corona y es sede real" (Ibn al Jatib 1997: 130-131). La alcazaba cumple por tanto la función de sede del poder, sea directamente en la persona del regente o en su delegado, el alcaide. Los de Guadix tendrían hasta final del período nazarí la facultad de elegir a los alcaides de las fortalezas menores dentro de la amplia jurisdicción de la ciudad (Trillo 2007: 283). Este hecho se reflejará en la materialidad arquitectónica, como veremos.

Sin embargo, la imagen actualmente visible del conjunto fortificado se debe en gran medida a las profundas transformaciones llevadas a cabo durante la ocupación francesa (1810-1812) y a la restauración a la que se vio sometida tras la Guerra Civil (Fig. 3). Esta última, como las posteriores reparaciones sufridas tras convertirse en el patio del Seminario Menor, fueron realizadas sin criterio científico y con materiales contemporáneos o reutilizados. Estas intervenciones dificultan en gran medida la lectura y el análisis de la secuencia y las técnicas constructivas de la alcazaba en general y la torre-puerta en particular, pero son al mismo tiempo una parte esencial de la historia del edificio y de la ciudad.

Las últimas actuaciones llevadas a cabo en la alcazaba han estado relacionadas con la idea de recuperarla. Entre ellas, contamos hasta la fecha con tres excavaciones, que han permitido profundizar más en el conocimiento de esta fortificación, aunque todavía queden muchas dudas por despejar. La primera fue ejecutada en el año 1986, realizándose seis catas en el interior del primer recinto (Fig. 4). En ellas se documentó un horizonte islámico, fechado entonces con bastantes dudas a partir de la cerámica en etapa califal - siglo X- Surgieron diferentes estructuras, destacando un muro estucado, una alberca asociada a una fuente y una conducción de agua, que fueron sin embargo interpretados por su excavadora como un aljibe (Raya 1987). Todo ello permite suponer que se tratase de un espacio de prestigio, vinculado probablemente a la residencia del alcaide aquí ubicada.

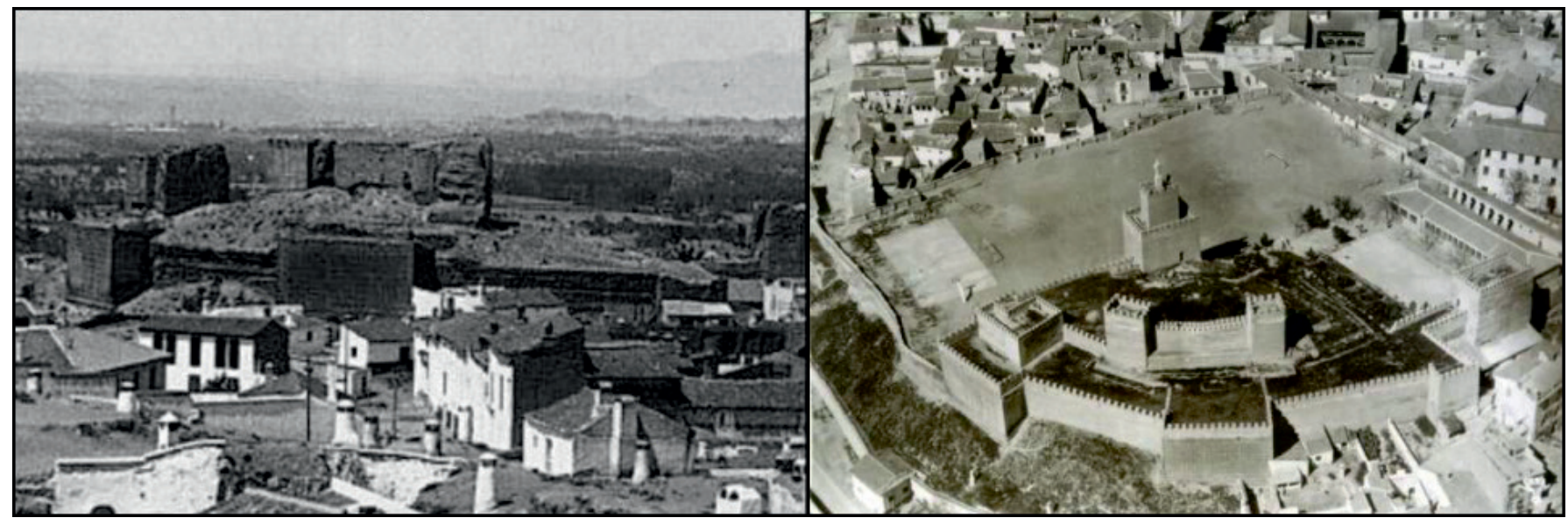

Figura 3. La alcazaba antes de la Guerra Civil (izq.) y en los años 60 (dcha.). Autores desconocidos. Archivo General de la Administración 33, F, 00118, 09, 012 (izq.) y cedida por patrimonioguadix.es (dcha.). 
La siguiente excavación, y la más interesante para el presente trabajo, es la realizada en 2005 en la torrepuerta. Se planteó como apoyo a la restauración tras el mencionado derrumbe parcial de la estructura, lo que permitió comprobar que esta era hueca. La intervención se dividió en tres zonas: el interior de la propia torre, su exterior más inmediato hacia el norte y el oeste, donde se unen recinto exterior e interior. En el primer sector, bajo un derrumbe se documentó el nivel de uso original, datado en el siglo XI, y el arranque de las jambas del arco de acceso del mismo momento. En el segundo, se localizaron dos conducciones de agua, una de origen moderna y otra medieval. Vinculada a estas se encontró una estructura de habitación con un hogar, datada por la abundante cerámica de mesa como de época almohade y nazarí. En el último sector se descubrieron los restos del lienzo que unía el recinto exterior con el interior (Sarr y Reyes 2006).

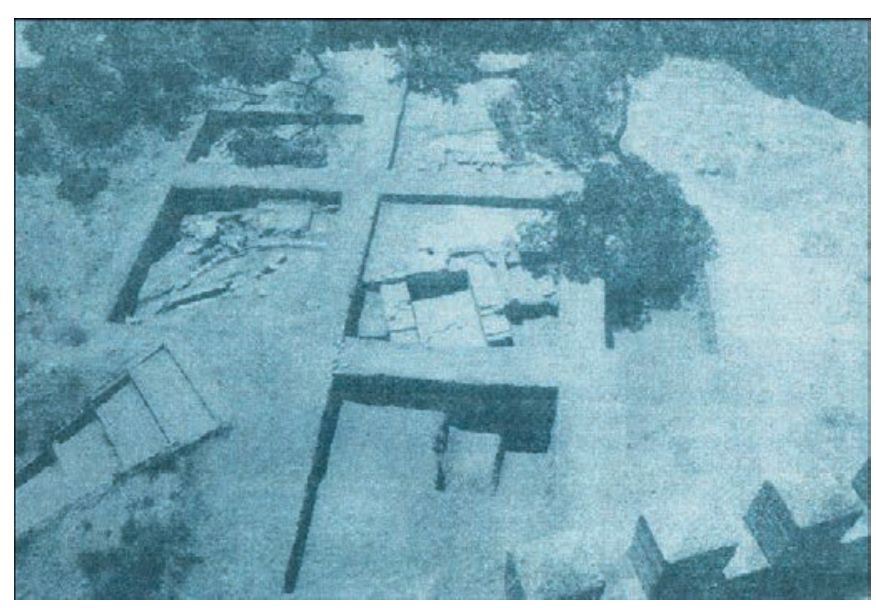

Figura 4. Sondeos arqueológicos de 1986 en el interior del primer recinto de la alcazaba (Ramírez 2017).

La intervención más reciente data del año 2009, ejecutada en el contexto del proyecto de creación de un parque arqueológico que quedó paralizado hasta la actualidad. Se realizó un sondeo en el interior y otro en el exterior de la puerta del recinto norte. Además, se abrieron otros dos en el terraplén externo de la calle Muralla que permitieran valorar el estado de conservación de este recinto. De este modo, se logró identificar la puerta norte original de la alcazaba, compuesta por dos torres en tapial de calicanto, con una altura de 10 $\mathrm{m}$ la oriental y $6 \mathrm{~m}$ la occidental debido a la pendiente. $\mathrm{Su}$ interior fue desmantelado durante la etapa en la que las tropas napoleónicas se acuartelaron en la alcazaba. A este acceso se llegaba mediante una rampa que salvaba el desnivel entre el interior de la alcazaba y el exterior, forzando a un doble recodo desde época almohade. En una fase anterior, también documentada, el ingreso se realizaría con un eje directo. Además, también se halló bajo el pavimento de la calle actual restos del bastión que protegía esa rampa. Vestigios de esta posible defensa adelantada se hallaron asimismo en uno de los sondeos realizados en Travesía de la Muralla. En ambos se observó que, bajo gran cantidad de rellenos contemporáneos, las murallas del tercer recinto se encuentran en un excepcional estado de conservación, con más de $5 \mathrm{~m}$ de potencia bajo la cota actual. Se pudo así mismo documentar la actuación de las tropas napoleónicas, rellenando los flanqueos de las torres y enrasando el interior de la alcazaba hasta el nivel del adarve, de forma que se ganase espacio útil como cuartel. Por último, se localizó en uno de los sondeos una fosa excavada en el sustrato geológico bajo los niveles de cimentación de la muralla con materiales del siglo $\mathrm{X}$, por lo que el tercer recinto estaría datado a partir del siglo XI y es, en realidad, el más antiguo (Martín Civantos 2010a: 50-51; Martín Civantos y Raya 2009: 288).

En paralelo a esta intervención, se comenzó en el marco del proyecto "De Acci a Guadix" un estudio de Arqueología de la Arquitectura de toda la alcazaba. Así, hemos podido documentar preliminarmente, como ya se avanzó en parte para el primer y el segundo recinto, una evolución general del conjunto dividido en seis grandes períodos (Rouco 2017).

El primero de todos, de época zirí y realizado en tapial de calicanto, se correspondería con el primer recinto de la alcazaba, como quedó documentado en la intervención de 2009. En una segunda fase, se erigen las dos torres occidentales de la barbacana. Estas se realizan en un tapial de calicanto ligeramente distinto y tapial hormigonado, probablemente a finales de la etapa taifa o en época almorávide. La tercera fase supone la mayor transformación del complejo, añadiéndose la torre oriental a la barbacana y construyéndose el recinto interior. Se crea también el acceso en doble recodo a la puerta norte del perímetro exterior. Estas modificaciones se realizan en tapial calicostrado, técnica constructiva documentada desde el siglo XII y durante el período nazarí (Martín García 2009). La cuarta fase se corresponde con las reformas castellanas tras la conquista de la ciudad en 1489, que afectaron en gran medida a la torrepuerta como veremos. La quinta fase es la actuación a principios del XIX de las tropas francesas que, como ya se mencionó, alinearon el recinto exterior y rellenaron el 
interior de la alcazaba con materiales desmantelados de la misma (Martín Civantos y Raya 2009; Soler 2013). Por último, la sexta etapa engloba las restauraciones y reparaciones realizadas durante la segunda mitad del siglo $\mathrm{XX}$.

\section{METODOLOGÍA}

La metodología empleada para el estudio de la torrepuerta se centra en la lectura estratigráfica del complejo estructural, integrando los resultados de la excavación de 2005, y la caracterización de las técnicas constructivas. Para ello nos hemos servido además de un importante aparato gráfico, que es fundamental para comprender el edificio y analizar sus materiales y fases constructivas. Este ha incluido un levantamiento completo en 3D que permita plasmar de forma adecuada el análisis arqueológico realizado. El proceso de documentación y análisis de la torre-puerta ha requerido de una correcta planificación del flujo de trabajo que podemos sintetizar en los siguientes apartados:

Tareas de campo: consistentes en el análisis y captura de datos. Se han realizado las siguientes etapas: a) georreferenciación del edificio en coordenadas universales; b) captura sistemática de imágenes para el posterior modelado fotogramétrico; c) análisis minucioso de las UEs y su registro en fichas.

Trabajos de laboratorio: se han seguido los siguientes pasos: d) modelado tridimensional de la estructura a partir de las imágenes; e) obtención de documentos gráficos (ortofotografías de planta, alzados y secciones); f) análisis y gestión de la información arqueológica sobre plataformas digitales.

\section{a) Georreferenciación del yacimiento y estructura:}

La primera fase consistió en la geolocalización de la torre en el sistema de referencia universal (UTMETRS89), utilizando para ello un equipo de posicionamiento global en tiempo real DGPS conectado a la Red Nacional de Instituto Geográfico, que le proporciona correcciones en tiempo real permitiendo la captura de las coordenadas de puntos base con una precisión de 1 a $2 \mathrm{~cm}$ dependiendo del número y geometría de los satélites. Para estos trabajos se ha utilizado un equipo DGPS Leica Smart-Rovert 1200. Estos puntos han servido de base para el estacionado y posterior medición de puntos de apoyo fotogramétrico mediante distanciometría laser.
El equipo utilizado ha sido una Estación Total Leica TS06. Estos puntos permitirán escalar y orientar el modelo tridimensional para que sea preciso.

b) Captura de imágenes:

La falta de accesibilidad para la captura desde tierra mediante cámara réflex motivó la utilización de un equipo UAV (Vehículo Aéreo No-tripulado) que ha permitido una captura sistemática de imágenes desde todos los puntos de vista. El equipo utilizado ha sido un drone DJI phantom2 visión plus que incorpora una cámara FC200 con un sensor $1 / 2.3$ " y 14 megapíxeles $(4384 \times 3288)$ de resolución geométrica para un campo de visión de $110^{\circ}$. Por el contrario, la imposibilidad de volar en el interior de la torre debido a sus pequeñas dimensiones ha necesitado de la utilización de una cámara réflex, modelo Nikon D800 de 36 megapíxeles con un objetivo fijo gran angular Nikkor de $14 \mathrm{~mm}$ de distancia focal (Fig. 5).

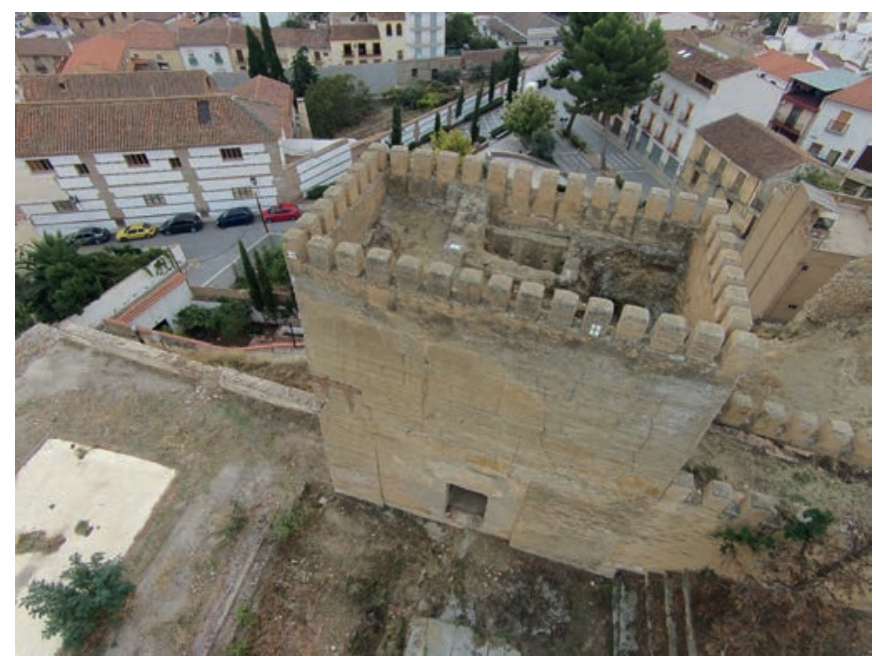

Figura 5. Captura mediante UAV DJI Phanton 2 visión plus del alzado norte de la torre-puerta.

Para garantizar la precisión y resolución del modelo 3D se han tenido en cuenta un correcto ajuste de las variables geométricas y radiométricas de las imágenes. Se han utilizado cámaras con focal fija, eligiendo un día nublado para evitar los problemas de exposición. Igualmente ha sido necesario un calibrado las imágenes para eliminar los errores de distorsión de la lente.

c) Análisis arqueológico y registro en fichas:

En el marco del estudio completo de la alcazaba, la dividimos en dos áreas. La 10.000 se corresponde con los 
dos recintos interiores y la 20.000 con el exterior. Una vez realizada esta diferenciación, los restos se articulan en tres niveles jerarquizados para su análisis, que son de mayor a menor:

- Complejo Estructural (CE): conjunto de Es articuladas entre sí que conforman un espacio físico con una funcionalidad determinada.

- Estructura (E): agrupación de UEs que cumplen una misma funcionalidad estructural.

- Unidad Estratigráfica (UE): elemento menor individualizable estratigráficamente a partir de su composición y su técnica constructiva (Brogiolo 1988: 12-20; Parenti 1995: 21).

Estos tres elementos se individualizan mediante la observación directa en campo y sus límites son trazados directamente en la ortofoto. Sus características son registradas en fichas, teniendo en cuenta básicamente los rasgos individuales de cada unidad: superficie, contorno y relieve, posición topográfica, posición estratigráfica y cronología absoluta. La alcazaba en su conjunto está formada por $35 \mathrm{CEs}, 96$ Es y algo más de 650 UEs (Fig. 6).

El principal objeto de estudio son las relaciones de anteroposterioridad y contemporaneidad entre los distintos elementos que conforman los tres niveles de análisis (Parenti 1996: 77-83), obteniendo la secuencia evolutiva de cada $\mathrm{E}$ a partir de las relaciones estratigráficas de cada UE, plasmándose en una matriz de Harris. Una vez obtenemos las secuencias de todas las Es, realizamos la interpretación de la evolución constructiva de los distintos CEs que componen la alcazaba. Es necesario matizar que, respecto a las relaciones estratigráficas tradicionalmente observadas, realizamos una modificación. Se trata del caso de las UEs negativas

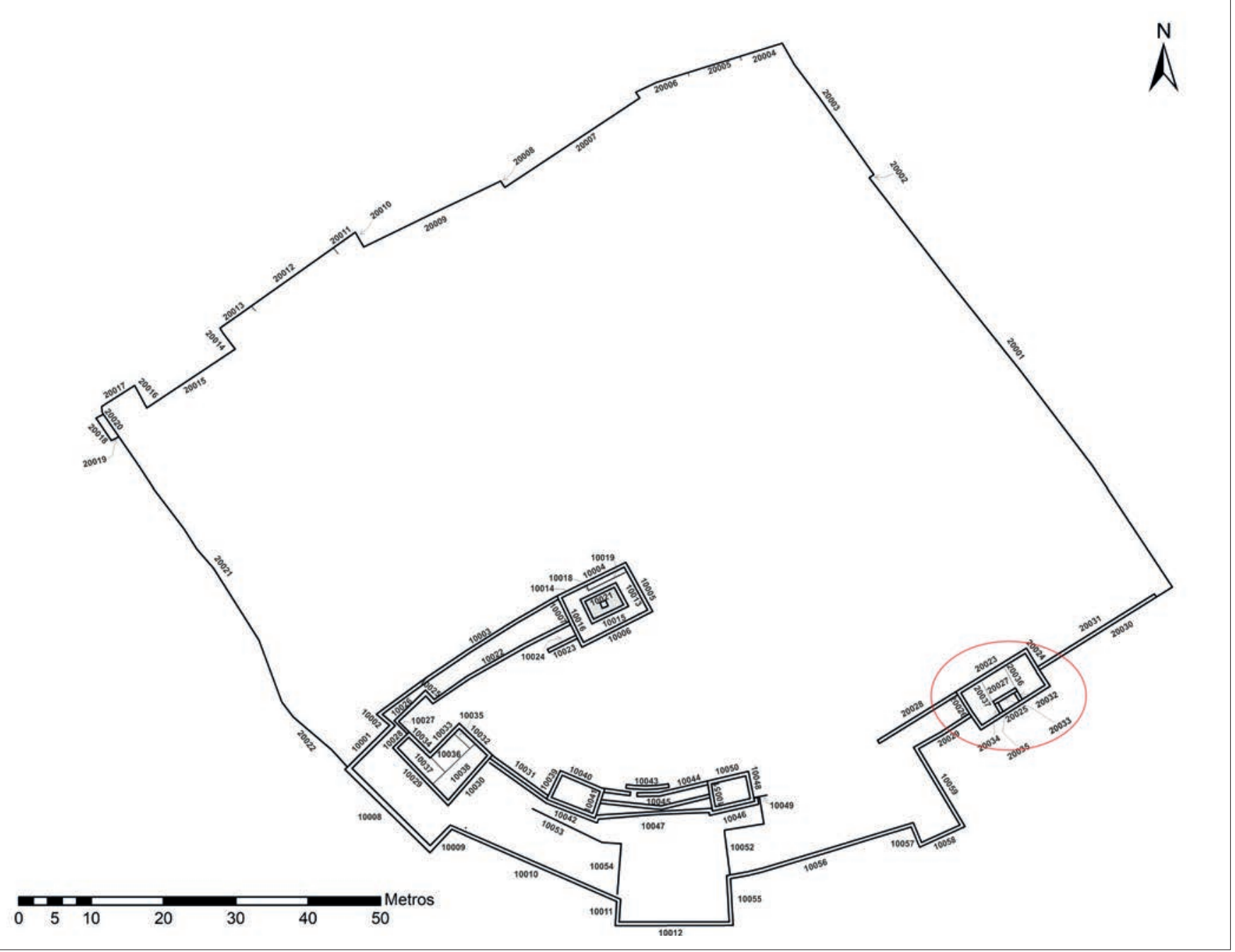

Figura 6. Estructuras de la alcazaba y ubicación de la torre-puerta. 
que son resultado de la apertura de un vano, pero en fase con el paramento. La negativa necesariamente corta al paramento, por lo que sería posterior a este. Sin embargo, al ser el resultado de un vano dejado en el momento de la construcción, es en realidad contemporáneo y no posterior a la UE positiva. Por tanto, pese a mantener la relación de corte, lo consideramos coetáneo.

Como ya hemos mencionado, la restauración de la segunda mitad del siglo XX provocó el enmascaramiento de numerosas UEs de las fases precedentes $\mathrm{y}$ sus relaciones estratigráficas, lo que, si bien dificulta la investigación, no la imposibilita. La abundante presencia de parches y revocos en mortero contemporáneo provoca que hayamos optado por simplificar el número de UEs identificadas de este período si su entidad no era considerable o no aportaba información significativa a la interpretación de la secuencia estratigráfica. En el mismo sentido de evitar un virtuosismo estratigráfico que multiplicaría de forma innecesaria los elementos a documentar, como ya han tratado diversos autores (Brogiolo 1988: 71-77; Parenti 1988), no individualizamos los varios componentes de una misma fábrica. Ejemplo de ello son los mechinales visibles en distintos puntos del tapial, a los que consideramos como parte de la misma UE al tratarse de huellas de la técnica constructiva, no de acciones o momentos diferentes en la secuencia (Tabales 2002: 89).

La caracterización de técnicas constructivas, por su parte, se realiza en función de sus elementos definitorios: elaboración de los materiales, aparejo y sección del muro, dimensiones, acabado final y tipo de mortero o ausencia del mismo (Parenti 1996: 77-78). A partir de este análisis, podemos contrastar y equiparar fases dentro de los distintos CEs y, atendiendo a los estudios sobre cronotipologías realizados en el territorio de Granada y de las propias excavaciones realizadas en la alcazaba, proponer dataciones absolutas.

\section{d) Modelado tridimensional de la estructura:}

El modelado de la torre-puerta se ha realizado a través de métodos fotogramétricos mediante tecnología SFM - Structure from Motion - (Benavides 2017; Benavides et al. 2016; Pereira 2016), utilizando para ello el programa Agisoft-Photoscan Pro ${ }^{5}$. Esta tecnología permite la orientación y ajuste de las imágenes mediante la combinación de los algoritmos SIFT — Scale Invariable Feature Transform - (Lowe 1999) y Bundler (Snavely 2010) (Fig. 7).

Conocida la posición y orientación de cada una de las cámaras procedemos por triangulación múltiple a la creación de un modelo tridimensional de millones de puntos. La indefinición de formas que genera esta nube de puntos es corregida mediante la generación, a partir de ellos, de una superficie irregular TIN (Triangular Irregular Network) y que se adapta fielmente a las irregularidades de las estructuras. Finalmente, la superficie es mapeada mediante la aplicación de las texturas de las imágenes proporcionando una visualización realista de los elementos de estudio ${ }^{6}$ (Fig. 8).

\footnotetext{
AGISOFT, L. L. C. 2014: Agisoft Photoscan Professional Edition. San Petersburgo.

6 El modelo tridimensional de la torre-puerta puede ser consultado y descargado libremente en: http://hdl.handle.net/10481/48695
}

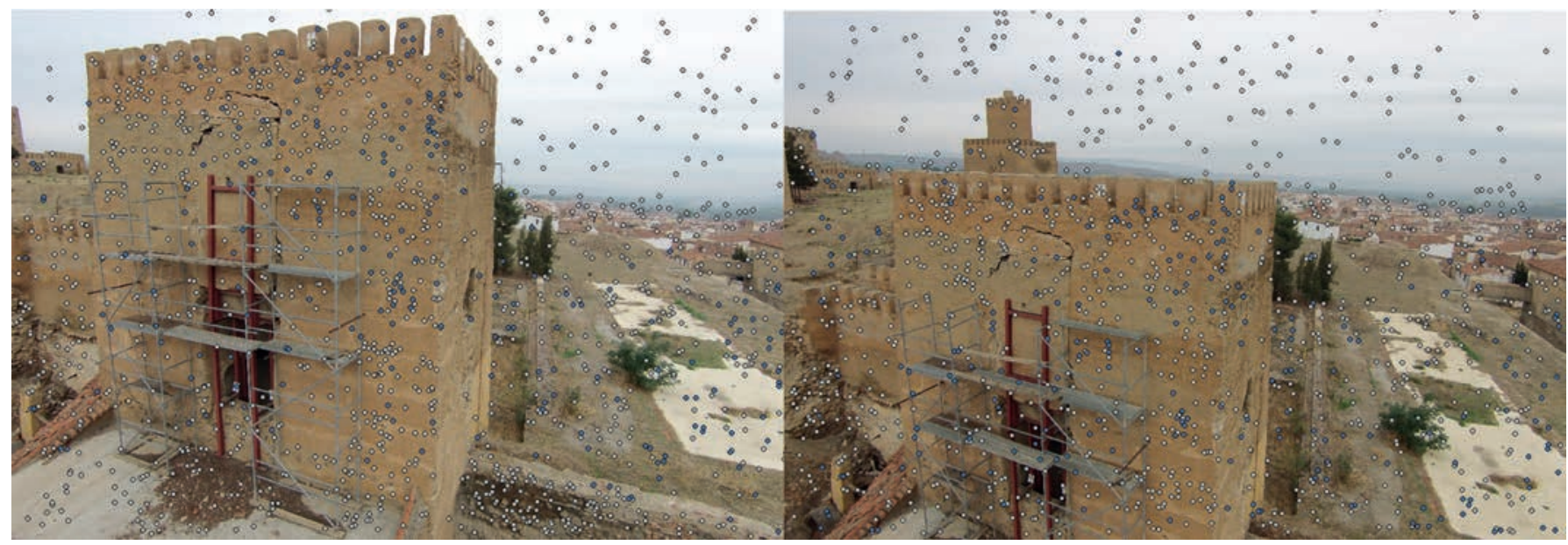

Figura 7. Correlación de dos imágenes del alzado sur de la torre-puerta a partir de puntos invariables de enlace radiométrico. 


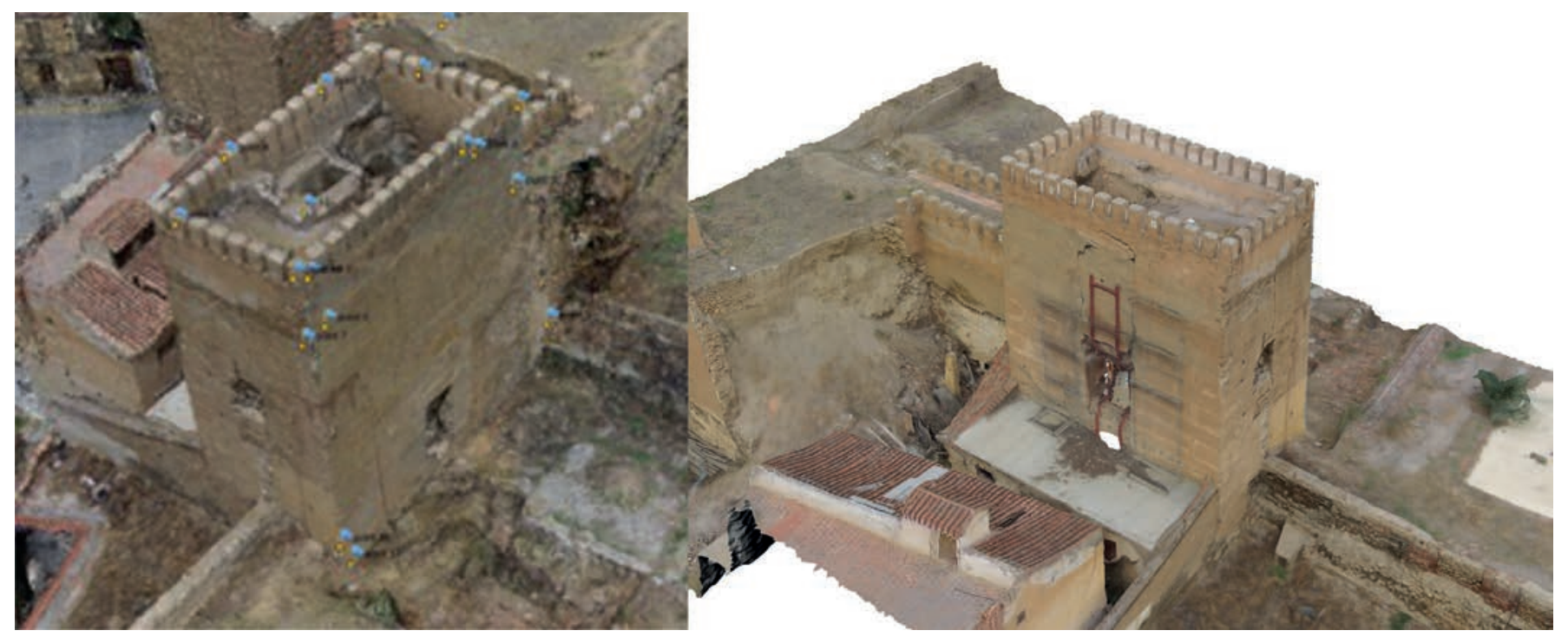

Figura 8. Modelo tridimensional mediante nube de puntos de la vista noreste de la torre-puerta obtenida por intersección múltiple de haces proyectivos (izq.). Vista sureste del modelo tridimensional de superficie texturizado (dcha.).

e) Obtención de documentos gráficos 2D (ortofotografías):

La enorme complejidad que supone el trabajo de documentación directa sobre el modelo 3D obliga a una necesaria simplificación mediante la obtención de vistas de planta, alzados y secciones. En este sentido, las ortofotografías, obtenidas mediante proyecciones paralelas del modelo 3D texturizado nos aportan una importante información de tipo cuantitativo (geometría y dimensión a escala del objeto de estudio) y cualitativo (tipo de material, estado de conservación, patologías, etc...), ampliando de este modo la diversidad de lecturas posibles de un mismo documento, dejando además constancia de la interpretación realizada (Fig. 9).
Este tipo de documentos, fácilmente compatible mediante archivos tipo JPG, TIFF o PDF, son utilizados como soporte, sobre plataformas CAD o GIS, para la digitalización del análisis arqueológico.

\section{f) Análisis y gestión informática del registro arqueológico:}

Una vez obtenemos las ortofotografías mediante la fotogrametría, se introducen en un Sistema de Información Geográfica, permitiendo la georreferenciación de todos los datos y su volcado en una base de datos con coordenadas absolutas. Así, se enlaza la documentación recogida para cada UE y se dibujan sus límites, pudiendo realizarse mediciones reales de los mismos.

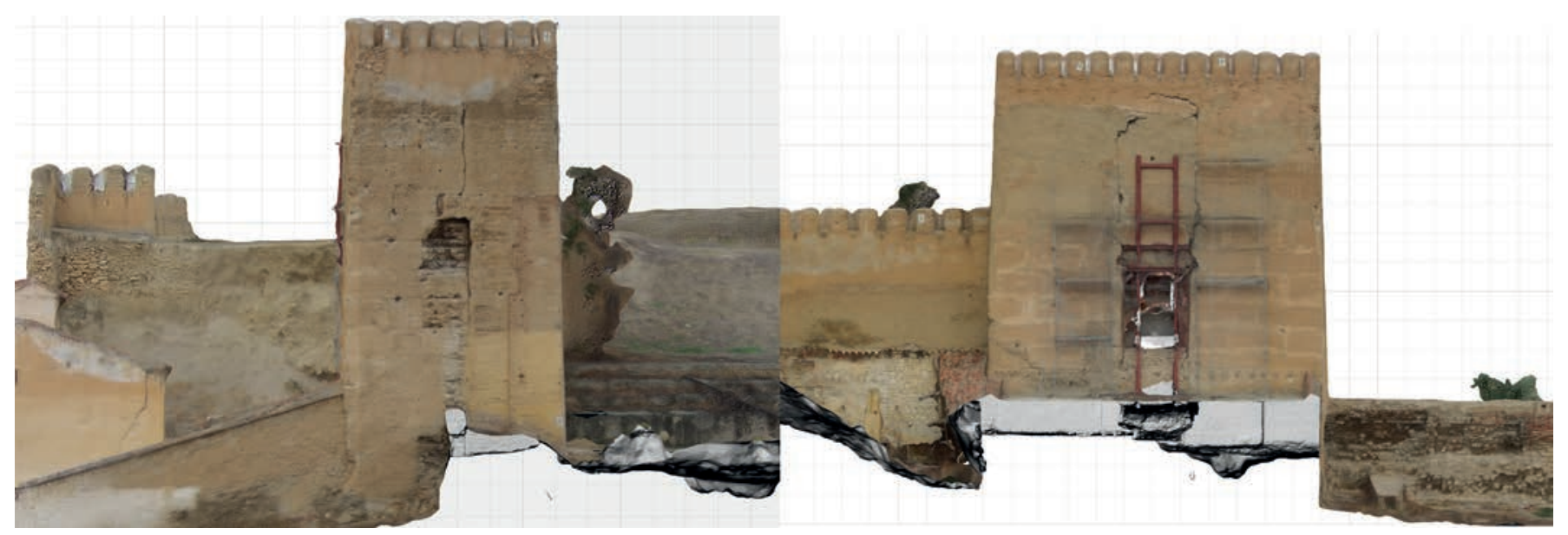

Figura 9. Ortoimágenes de los alzados este (izq.) y sur (dcha.) de la torre-puerta obtenidos a partir del modelo 3D. 
Este método resulta especialmente útil para los puntos de difícil acceso en campo y para revisar siempre que sea necesario las relaciones estratigráficas en laboratorio gracias a la calidad de los modelos tridimensionales. Sin embargo, la representación 3D en los SIG plantea numerosas dificultades en relación con el eje $\mathrm{Z}$ o cota. Esta problemática lleva varios años debatiéndose en el campo de la Arqueología, aunque todavía no ha resultado en una aplicación que posibilite trabajar realmente con planimetrías directamente en tres dimensiones con datos geoespaciales de forma práctica (Lanjouw 2016; Van Leusen y Van Gessel 2016). Por tanto, optamos por desplegar en horizontal la ortofoto de cada estructura en el punto en el que se alza. De esta manera, aunque los datos sobre sus coordenadas absolutas estén distorsionados respecto a la realidad, podemos trabajar sobre las planimetrías con medidas reales enlazadas directamente con su información alfanumérica.

\section{LA EVOLUCIÓN CONSTRUCTIVA DE LA TORRE-PUERTA}

La torre-puerta de la alcazaba de Guadix se sitúa en su extremo sureste, dominando la plaza Pedro de Mendoza. Era la comunicación externa de la fortificación. De aquí salía el camino en dirección al Zenete y Almería y se encontraba el cementerio musulmán, situado extramuros (Fig. 10). Se trata de un único CE, el 147. Tiene la secuencia más compleja de toda la alcazaba, por lo que supone una valiosa muestra para la comprensión de la evolución del conjunto desde su erección hasta la actualidad.

Actualmente, presenta una planta rectangular, con unas dimensiones de $6 \mathrm{~m}$ por $11 \mathrm{~m}$. Hacia el exterior del recinto, posee una altura sobre el nivel del suelo de $15,7 \mathrm{~m}$, mientras que hacia el interior solamente levanta $13 \mathrm{~m}$. Está compuesta por un total de 11 Es. La torre se traba al oeste con el CE 13 y al este con el CE 15, lienzos de la muralla. A continuación, describiremos las secuencias por estructura para comprender la evolución de la torre-puerta desde su construcción, insertando sus UEs en las fases constructivas del CE (Fig. 11).

\footnotetext{
7 La nomenclatura otorgada al CE de la torre-puerta es CE 20014, al encontrarse en el área 20000. Sin embargo, para agilizar la lectura del presente artículo y al no referirnos a CEs del área 10000, acortaremos su denominación a CE 14. Lo mismo sucede en el caso de las Es y las UEs, aunque en el aparato gráfico puedan aparecer con la nomenclatura sin abreviar.
}

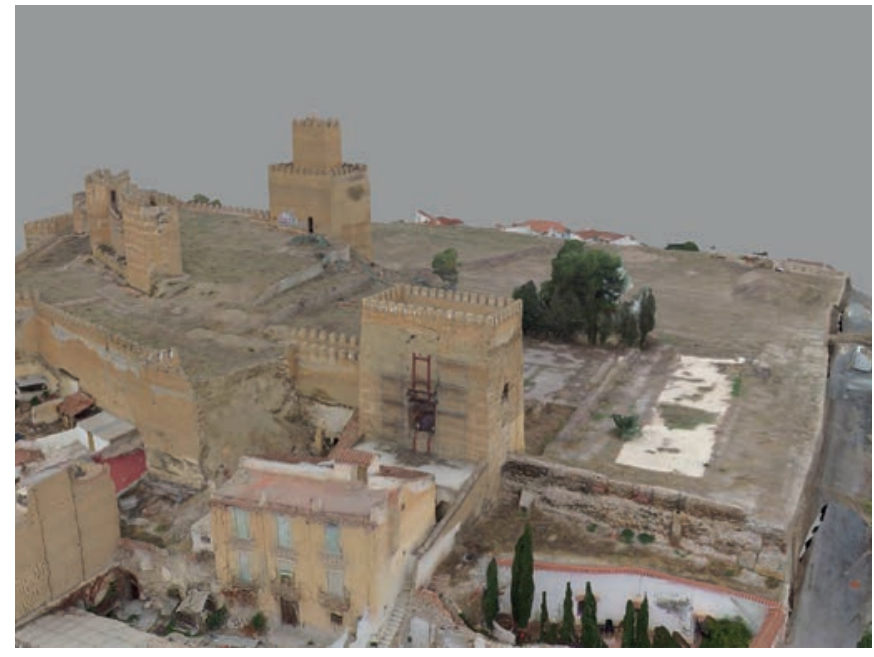

Figura 10. Modelo tridimensional de la torre-puerta desde el este (plaza Pedro de Mendoza).

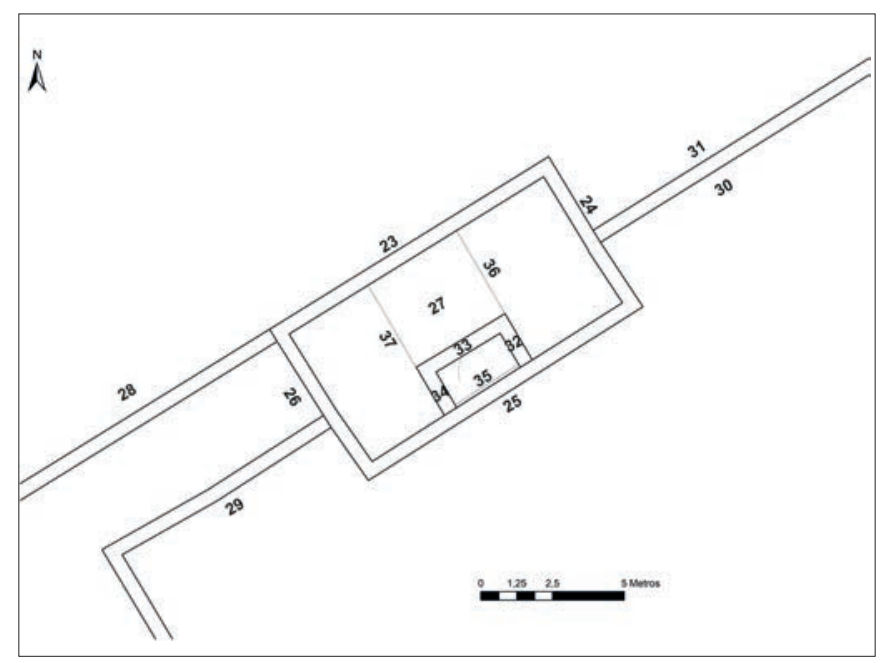

Figura 11. Estructuras de la torre-puerta.

\section{Estructura 23}

Se trata de la cara norte de la torre-puerta. Se traba al oeste con la E26 y al este con la E24 (Figs. 12 y 13). Su secuencia se inicia con tres UEs equivalentes. La más importante de ellas es la UE 175, situada en la parte superior del paramento, con unas dimensiones de 10 $\mathrm{m}$ de anchura por $5 \mathrm{~m}$ de altura. Esta UE rectangular es un tapial calicostrado de color marrón que conserva el enlucido original casi en su totalidad. De encofrado corrido, se observan las huellas de los clavos y también dos líneas verticales paralelas que podrían ser un costal interno tapado. Las agujas se conservan dentro de los mechinales y el tapial en la parte inferior sufre un cambio de coloración y se vuelve amarillento. Su 
módulo varía de 0,7 a $0,75 \mathrm{~m}$ de altura. Se ve afectado en su parte inferior por las reparaciones de época de la conquista castellana y el cemento contemporáneo. Se traba con la UE 220 de la E26 y con la 200 de E24. Las otras dos UEs realizadas con este tipo de tapial son 183 y 187 , con unas dimensiones mucho más reducidas. La UE 183 se sitúa en la parte inferior de la estructura, a la derecha de la puerta, con unas medidas de 1,3 $\mathrm{m}$ de largo por $0,7 \mathrm{~m}$ de ancho, siendo cubierta por la UE 177. La UE 187 se encuentra en la parte superior izquierda de la puerta, también con forma irregular y unas dimensiones de 0,5 por $0,6 \mathrm{~m}$.
Tras este primer momento, con la conquista castellana, la torre-puerta es reforzada con contrafuertes en ladrillo debido, seguramente, a que presentase ya problemas estructurales. Así, el tapial 175 es cortado por varias UEs $(196,197$ y 198) que serán rellenadas por los añadidos en ladrillo (UEs 176, 177, 179, 181 y 186).

La UE 196 corta a la 175 en la parte izquierda de la E, con una longitud de 4,6 m lineales, y se une a la UE 204 de la E24. Es rellenada por la UE 176, que es un machón ataludado de refuerzo de la estructura de 7,7 m de altura por 2,2 de anchura. Está realizado con un aparejo de ladrillo inglés típico de las fábricas mudéjares

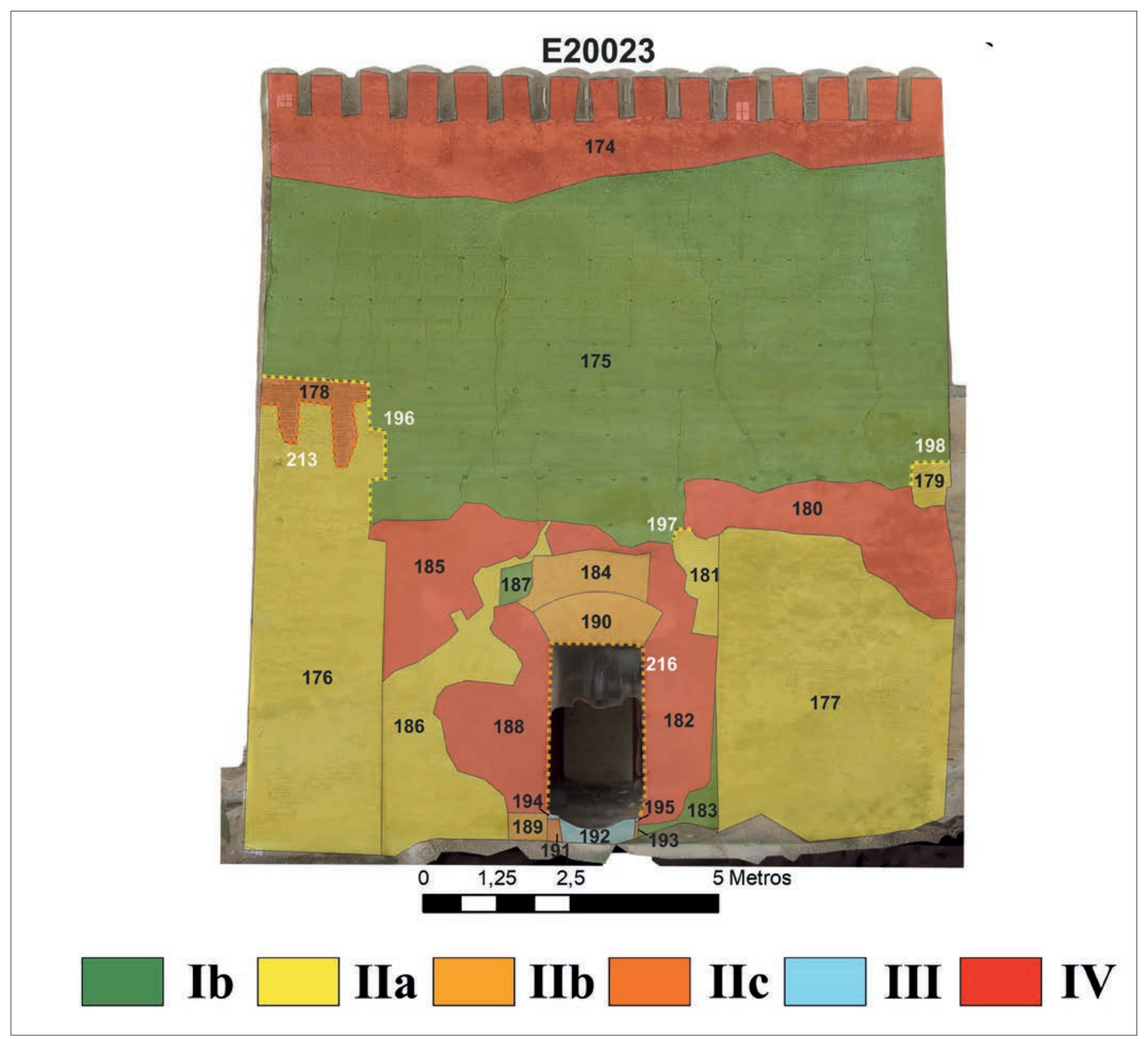

Figura 12. UEs y secuencia histórica de la E23. 
del XVI accitano (Gómez-Moreno 2009: 40-47), que alterna hiladas de sogas con hiladas de tizones, unidas con un mortero blanco de cal y arena. Los tizones miden $12 \mathrm{~cm}$ de largo por 3,5 de ancho, mientras que las sogas $27,5 \mathrm{~cm}$ de largo por 3,5 de ancho. Está recubierto con un enlucido de cal de color marrón en algunas zonas. Se traba con la UE 205 de la E24. En la parte superior de la UE 176 existe una reparación, realizándosele un corte irregular (213) que es rellenado por la UE $178(1,8 \mathrm{~m}$ por $1.4 \mathrm{~m}$ ), un parche irregular con ladrillo reutilizado y mortero de cal. La UE 176 se traba también a su derecha con la 186, que es otra unidad realizada con el mismo aparejo, pero sin talud. Su superficie es irregular al estar parcialmente cubierta bajo la UE 185. Sus dimensiones son de $5 \mathrm{~m}$ de altura por 2,2 de anchura.

En la parte derecha de la estructura, la UE 175 es cortada por la 197 (0,5 m de longitud), parcialmente oculta bajo la UE 180. A su vez, la UE 197 es rellenada por otro muro de ladrillo con el mismo tipo de aparejo (UE 181). Presenta unas medidas de 1,6 $\mathrm{m}$ de altura por $0,5 \mathrm{~m}$ de anchura. A su derecha se traba con la UE 177, otro machón ataludado equivalente a la UE 176, aunque más ancho y bajo que este $(5,1 \mathrm{~m}$ de altura por 3,9 de anchura). Por último, en el extremo derecho del paramento, hacia mitad de altura, la UE 175 es cortada por la 198 ( $1 \mathrm{~m}$ de longitud), que es rellenada por la UE 179, que es igualmente de ladrillo. Esta UE puede verse bajo un enlucido de cemento (UE 180) con unas dimensiones de $0,75 \mathrm{~m}$ por 0,6 , y sin duda se uniría con la UE $177 \mathrm{si}$ se retirara el revestimiento contemporáneo.

Una vez finalizada esta fase de refuerzos estructurales, se realizan modificaciones en la puerta. Por el tipo de fábrica se producirían poco después de la construcción de los contrafuertes. Apoyándose en la parte inferior derecha de la UE 186 se encuentra la UE 189. De forma rectangular, sus dimensiones son de $0,65 \mathrm{~m}$ de largo por 0,45 de ancho. Se trata del arranque de la jamba izquierda de la puerta, realizada con un aparejo irregular de ladrillo unido con un mortero de cal blanquecino. Los ladrillos están dispuestos mayoritariamente a modo de sogas con unas medidas de $24 / 25 \mathrm{~cm}$ de largo por 3,5/4 de ancho. De este momento es también la UE 190, situada en la parte superior de la puerta y cubierta por enlucidos de cemento (182 y 188). Es el arco adintelado del vano $(1,9 \times 0,8 \mathrm{~m})$, realizado con sogas y mortero oscuro, con una decoración incisa en el llagueado. La siguiente UE en la secuencia es el propio vano de la puerta (216), que corta tanto 189 como a 190, aunque en realidad esté en fase con ella. Tiene unas dimensiones de
$3 \mathrm{~m}$ de alto por 1,5 de ancho. Rematando esta reforma, tenemos la UE 184, que se apoya sobre la 190. Se trata de un aparejo de ladrillo cubierto de mortero marrón que probablemente sostuviese algún tipo de inscripción lapidaria. Conserva unas dimensiones de 1,95 por $6,9 \mathrm{~m}$.

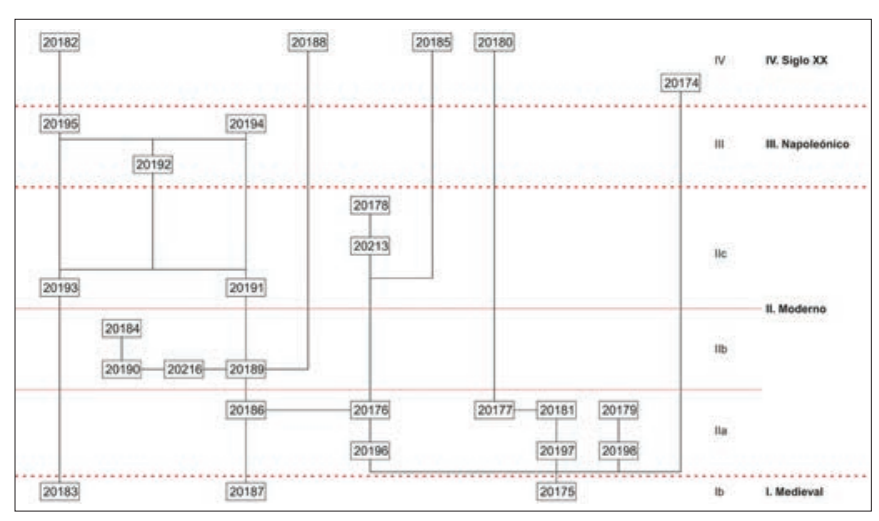

Figura 13. Matrix Harris de la E23.

Las transformaciones posteriores de la puerta resultan de difícil interpretación. Por ello, intentando perder la menor cantidad de información en una secuencia tan importante para la comprensión de la evolución de la alcazaba, se ha optado por no unificar las sucesivas modificaciones del tranco de la puerta y mantenerlas como fases distintas. Se inicia con un estrechamiento del vano de la puerta del que se conservan solo restos en la parte inferior. Se trata de las UEs $191(0,4$ por 0,2 m) y 193 $(0,3 \mathrm{~m}$ de altura por 0,1$)$, situadas respectivamente en la jamba izquierda y derecha. Son dos pilarillos de ladrillo irregular unidos con mortero blanquecino que se apoyan contra las jambas, rellenando a la UE 216.

Posteriormente, probablemente en época napoleónica, se reacondiciona de nuevo la puerta para adecuarla a los nuevos usos de la estancia interior de la torre, que detallaremos posteriormente. Se construye un pequeño murete, la UE 192 (1,2 m de largo por 0,4), apoyándose en 191 y 193. Se trata de un nuevo tranco situado en la parte inferior de la puerta que sube la cota del nivel de uso, realizado con un aparejo irregular de ladrillo único con mortero de cal blanquecino con poco árido. Por último, se realizan dos UEs con ladrillo y mortero de yeso de las que quedan escasos restos. Son la UE $194(0,2 \mathrm{~m}$ por 0,07$)$, que se apoya en 191 y 192 y la UE $195(0,05$ por 0,06 m), que se apoya en 193 y 192.

Para finalizar la secuencia constructiva, la restauración contemporánea reconstruye el pretil y la merlatura (UE 174), con materiales contemporáneos y una altura de 1,7 m. De este momento datan también diversos 
enlucidos en cemento. Se trata de las UEs 180, 182, 185 y 188. La primera, la UE 180 (4,5 m por 0,9 en sus ejes máximos), se sitúa en la parte derecha de la estructura y cubre a las UEs $175,177,179,181,197$ y 198 . La UE $182(4,7 \mathrm{~m}$ por 1,2$)$ se localiza en la parte derecha de la puerta, cubriendo a las UEs 181, 183, 184, 190, 193 y 195. En la jamba izquierda se encuentra la UE $188(3,5$ x $1,8 \mathrm{~m}$ ), que cubre a su vez a las UEs $184,186,187$, 189 y 190. Por último, arriba a la izquierda del vano se encuentra la UE $185(2,6 \mathrm{~m} \times 2,5)$, cubriendo a 175,176 y 186.

Por tanto, vista la evolución constructiva, podemos dividirla en cuatro períodos. El primero (con una única fase, Ib) se corresponde con el tapial calicostrado, probablemente de época almohade o principios de época nazarí (siglos XII-XIII), visible sobre todo en la UE 175. El siguiente período (II) data de la conquista castellana de la ciudad. Se inicia con la fase IIa y la construcción de los refuerzos en aparejo inglés de la E, como las UEs 176 y 177, y continúa con la reforma de la puerta interior (IIb), también en ladrillo (UEs 184, 189, 190 y 216). Cerrando esta etapa (IIc), se estrecha el acceso mediante cuatro UEs realizadas con ladrillo y mortero de cal $(178,191,193,213)$. El último cambio en la puerta se produce en el período III, cuando aumenta la altura del zócalo con un aparejo de ladrillo irregular con mortero de yeso $(192,194,195)$. Estas modificaciones probablemente tengan lugar en época napoleónica por el tipo de material reutilizado, documentado en otras partes de la alcazaba y en las reformas del interior de la torre-puerta. El último período (IV) se corresponde con la intervención de posguerra, construyéndose el pretil (UE 174) y los distintos enlucidos de cemento.

\section{Estructura 24}

La cara este de la torre-puerta, se traba al norte con E23 y al sur con E25 (Figs. 14 y 15). La secuencia se inicia con la UE 201. Se trata de la torre y el arranque de la muralla original en tapial de calicanto, con cantos gruesos y un mortero rico en cal. El encofrado se realiza en cajones, colocándose los tablones del esquinero en vertical. Los mechinales son de gran tamaño y el módulo del cajón es más alto que el del tapial calicostrado (UE 200), de 0,85$0,9 \mathrm{~m}$ frente a $0,7-0,75 \mathrm{~m}$. Su anchura resulta muy difícil de concretar. Las juntas estaban enlucidas y se conserva un gran resto de enlucido en la parte superior. Se traba con la UE 210 de la E25. Las roturas posteriores de los arranques de los cajones de la muralla (UEs 202, 206 y 207) permiten ver el núcleo de la UE 201. Su forma es rectangular y sus dimensiones son de 9,1 $\mathrm{m}$ de alto por 3,7 de ancho.

A la UE 201 se le apoya la UE 200. Se trata de un tapial calicostrado de encofrado corrido en el que no se aprecian cuerdas en las tablas. En la parte inferior de la UE, en la que se conserva bien el paramento, se observan las marcas de las cabezas de los clavos y enlucidos tapando las agujas con huellas a espiga similares a los de la torre del homenaje del recinto superior. Sus dimensiones son de $6,4 \mathrm{~m}$ de longitud por $7,1 \mathrm{~m}$ de altura. Se traba con la UE 175 de la E23 y con la 211 de la E25.

Posteriormente se introducen los refuerzos en ladrillo tras la conquista castellana al igual que vimos en la anterior estructura. En la parte derecha se realiza un largo corte de 7,9 $\mathrm{m}$ de longitud total (la UE 204), que se une con la UE 196 de la E23. La UE 204 fue rellenada por la UE 205, un machón ataludado que refuerza la esquina de la torre de $6,2 \mathrm{~m}$ de altura por 0,7 de anchura. Está realizado con un aparejo inglés excepto en la parte que toca con el tapial, donde se aprecian algunas irregularidades para adaptarse a la antigua fábrica. Presenta dos mechinales y se traba con la UE 176 a su derecha y con la 209 a su izquierda. En la parte superior de la UE 205 se realiza una reparación equivalente a la de la E 23, con un corte (UE 214) rellenado por UE 215. Este es un parche con ladrillo con mortero de cal que intenta imitar el aparejo inglés, pero al adaptarse al hueco resulta irregular. Tiene unas dimensiones de $1 \mathrm{~m}$ por $1,4 \mathrm{~m}$ y se traba a la UE 178 de la E23. La UE 209, por su parte, es un refuerzo de la pared de la torre con el mismo aparejo que 205, pero sin talud. Presenta unas medidas de 3,15 $\mathrm{m}$ por 1,3 .

Tras este reforzamiento, se produce la rotura de la antigua muralla, quedándose marcadas las improntas (UEs 202, 206 y 207, de abajo a arriba) del arranque de los cajones del lienzo que estaban trabados con la UE 201.

Por último, apoyándose sobre la UE 200, se reconstruye el pretil y la merlatura con materiales contemporáneos (UE 199). Se realizan además dos enlucidos de cemento: la UE 203 (1,7 m por 0,8$)$, que cubre a la UE 205 , y la UE 208 (2,5 m por 1), situada en la parte inferior del paramento y que cubre a la UE 201.

La secuencia de la E24 se divide en tres períodos. La época medieval (I) se divide en dos fases: Ia supone la construcción de las primeras torres que flanqueaban el acceso a la alcazaba en época zirí, siendo la UE 201 los restos de la cara oriental de la torre este de la antigua 


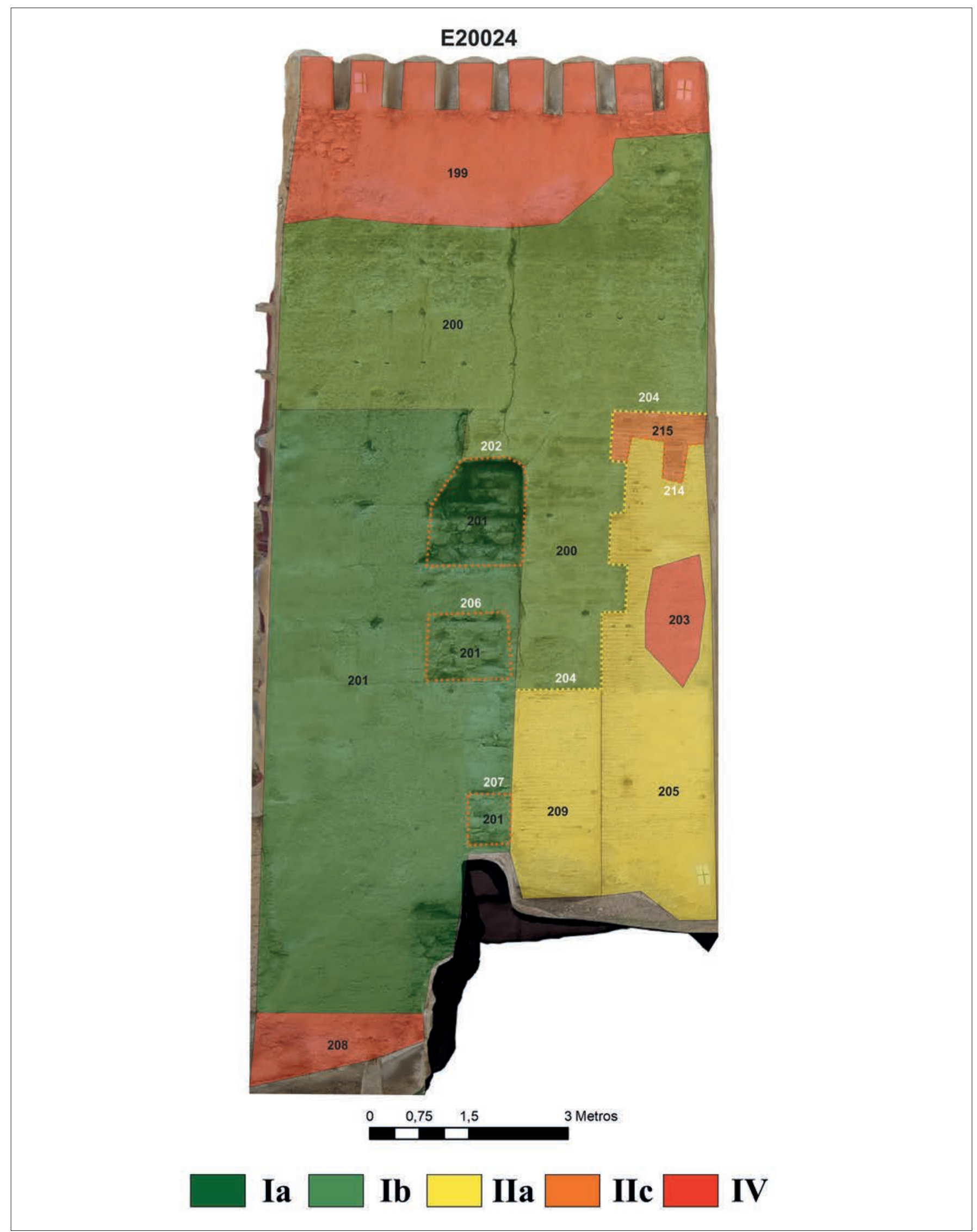

Figura 14. UEs y secuencia histórica de la E24. 
entrada. Se trata del mismo tipo de fábrica de calicanto documentado en todo el recinto exterior (Martín Civantos y Raya 2009; Rouco 2017). En la fase Ib, de época almohade o principios de la nazarí, las torres que flanqueaban el acceso y la muralla se recrecen y engrosan en tapial calicostrado (UE 200).

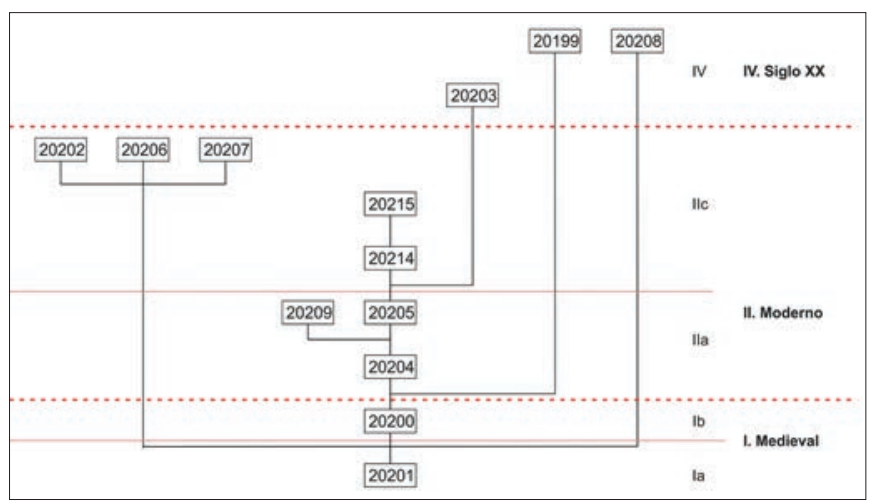

Figura 15. Matrix Harris de la E24.

El período moderno (II) vuelve a dividirse en dos fases: IIa se corresponde con los refuerzos en ladrillo de época de la conquista (UEs 204, 205, 209) y a la reparación formada por 214 y 215 . Por su parte, IIc es la rotura de la muralla original de la alcazaba $(202,206$ y 207), cuando esta ya ha perdido su función defensiva. Esta destrucción quizás puede retrasarse hasta la etapa napoleónica (III), momento en el que se construyó una nueva puerta de acceso a la alcazaba actualmente desaparecida, aunque no es posible afirmarlo con seguridad (Fig. 16). En el último período (IV), se ejecuta la reconstrucción de posguerra con la merlatura restituida y los parches de cemento (UEs 199, 203 y 208).

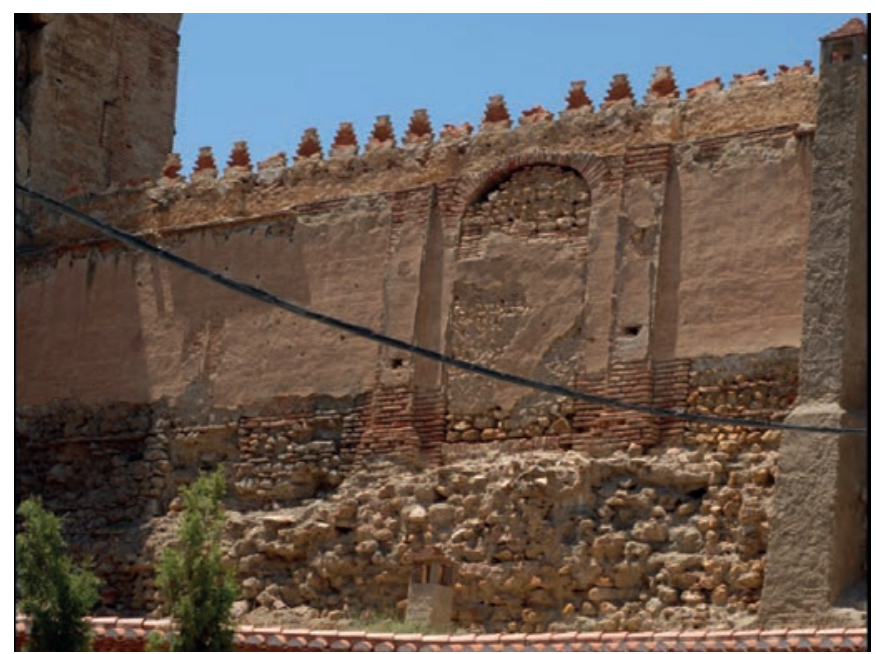

Figura 16. Antigua puerta de acceso realizada por las tropas napoleónicas, hoy desaparecida.

\section{Estructura 25}

Es la cara sur de la torre-puerta. Se traba a su derecha con E24 y a su izquierda con E26 (Figs. 17 y 18). La secuencia se inicia con dos UEs de tapial de calicanto en la parte inferior (UEs 210 y 230). La UE 210 (3,9 $\mathrm{m}$ de longitud por 4,5 de altura) tiene las juntas de los cajones enlucidos y presenta las mismas características que el tapial de calicanto del resto del recinto exterior. La UE 230 (4 m de longitud por 4,7 de altura) se sitúa en la parte izquierda, con las mismas características que la 210. Se traba a la UE 222 de la E26. En la parte inferior de ambas se apoya el tejado de la casa-cueva de época contemporánea que se sitúa bajo el CE.

Posteriormente en la secuencia, de manera análoga a la E24, tenemos el tapial calicostrado. Se observan bajo los enlucidos de cemento de la parte superior de esta fachada tres UEs: 211, 225 y 229 . Sus fábricas son idénticas a las del resto de tapiales calicostrados de esta torre-puerta. La primera (UE 211) es la más grande de las tres, situada en la parte superior derecha de la torre. Es un rectángulo de $3,7 \mathrm{~m}$ por $2 \mathrm{~m}$. Se apoya en la UE 210 y es cubierta por las UEs 224, 226 y 227. Las otras dos UEs (225 y 229) se encuentran también en la parte superior de la torre y son cubiertas por 224, la primera en el extremo izquierdo del paramento y la segunda en el centro.

Tras este recrecimiento se realiza una reforma en la puerta creando una especie de buhedera al cerrar el espacio que había entre las dos torres, enrasando las fachadas con un nuevo muro que apoyaba sobre cuatro rollizos embutidos en el tapial de calicanto. Para ello, se practicaron dos cortes (UEs 290 y 292) en las torres de calicanto (UEs 210 y 230 respectivamente). Estos cortes sirven para recibir los maderos que sostenían el nuevo muro de tapial. La colocación se hizo rellenando las dos interfaces con mortero de cal. Así, la UE 290 es rellenada por la $291(0,35$ $\mathrm{m}$ x 0,29) y la UE 292 por la $293(0,15 \mathrm{~m}$ x 0,34). Estos rollizos soportan a la UE 217 . Se trata de un muro de tapial calicostrado que enrasa las dos torres de flanqueo y se apoya contra ellas, creando así una buhedera frente a la puerta de entrada original. El colapso de estos rollizos provocó el derrumbe parcial del año 2005. Con la construcción del muro de la buhedera (UE 217) surge un nuevo vano de acceso (UE 251) entre las dos torres, adelantado respecto a la puerta original, con unas dimensiones de 2,2 $\mathrm{m}$ de altura por $2 \mathrm{~m}$ de anchura. Posteriormente, esta entrada es tapiada por las tropas napoleónicas por un muro de cantos unidos con mortero de cal (UE 228), que solo se conserva en la parte inferior del vano $(2,5 \mathrm{~m} \mathrm{x} \mathrm{1,3)}$. 


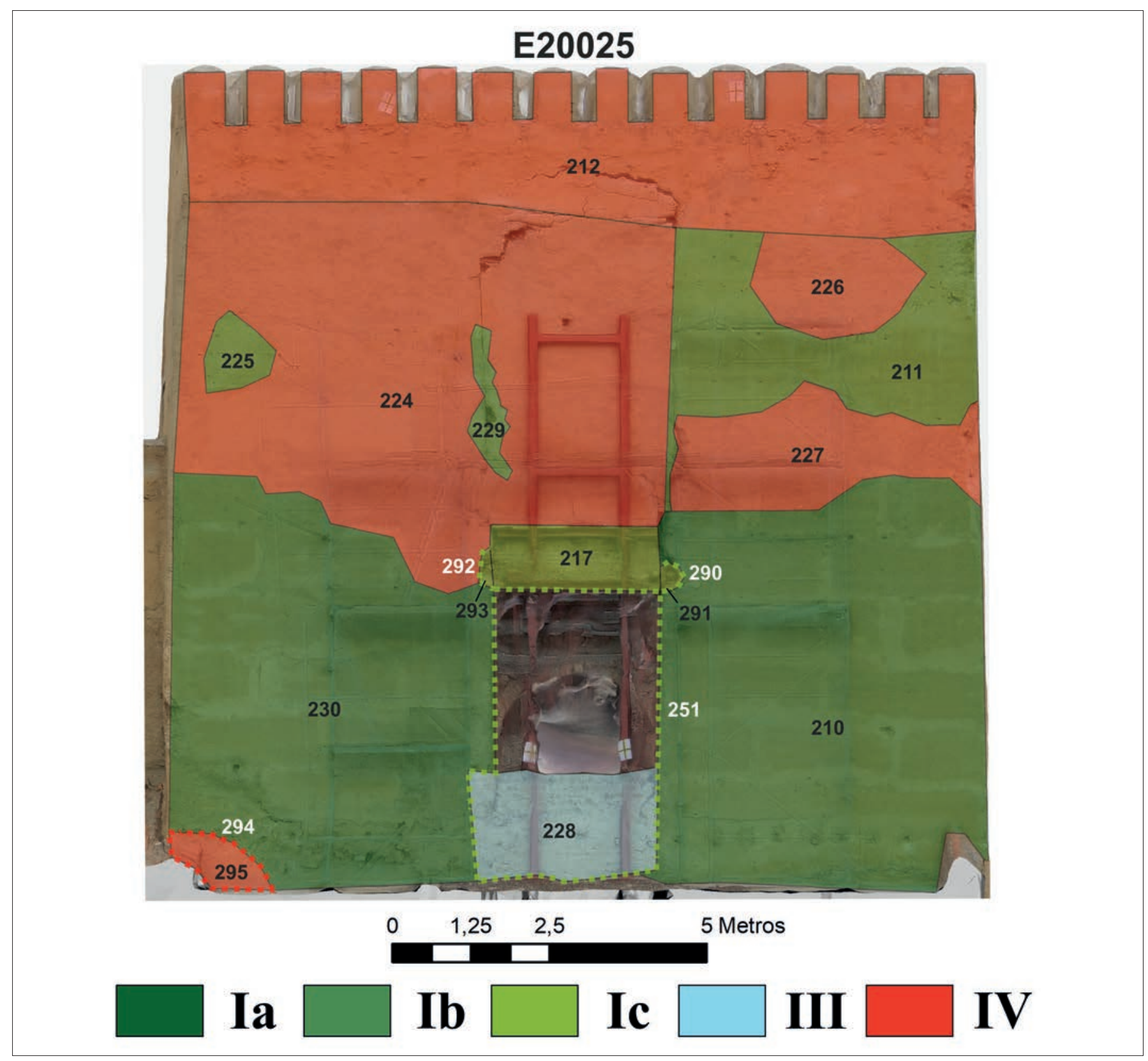

Figura 17. UEs y secuencia histórica de la E25.

Por último, igual que en las otras Es, se producirá una intervención de restauración tras la Guerra Civil. Sobre el tapial 211 se reconstruye el pretil y la merlatura con material contemporáneo (UE 212). En la parte inferior izquierda del paramento se produce una rotura (294), que es reparada con un parche de mampostería y cemento de $1 \mathrm{~m}$ de anchura por 0,7 de altura (UE 295). Finalmente, se enluce con cemento la estructura (UEs 224, 226 y 227). Uno de los enlucidos (UE 224) ocupa gran parte de la zona superior izquierda del paramento, con unas dimensiones de 5,9 $\mathrm{m}$ por 4,7 $\mathrm{m}$. Cubre a las
UEs 211, 212, 217, 225, 229, 230, 292 y 293. El otro (UE 226) se encuentra en la parte superior derecha con unas dimensiones de $2,1 \mathrm{~m}$ por 1 . Por último, la UE 227 (3,7 $\mathrm{m}$ por $1,5 \mathrm{~m}$ ) se encuentra bajo el enlucido anterior (UE 226), cubriendo a su vez a los tapiales de una de las torres (UEs 210 y 211).

Por tanto, podemos concluir que la secuencia constructiva de la E25 se encuentra dividida en tres períodos: medieval (I), napoleónico (III) y contemporáneo (IV). El medieval se divide en tres fases. Ia es la primitiva entrada zirí del s. XI, conservándose parte de la cara sur 
de la antigua torre oeste (UE 230) y de la este (UE 210), realizadas en calicanto. En la fase Ib, del siglo XII o ya del XIII, se recrecen las torres con tapial calicostrado (UEs 211, 229 y 225). Por último, Ic se corresponde con la buhedera realizada de forma tan precaria, probablemente como solución temporal para reforzar la defensa. Resulta de difícil datación por la tipología constructiva del tapial calicostrado, pudiendo ser todavía de época nazarí o alcanzar los inicios de la época moderna.

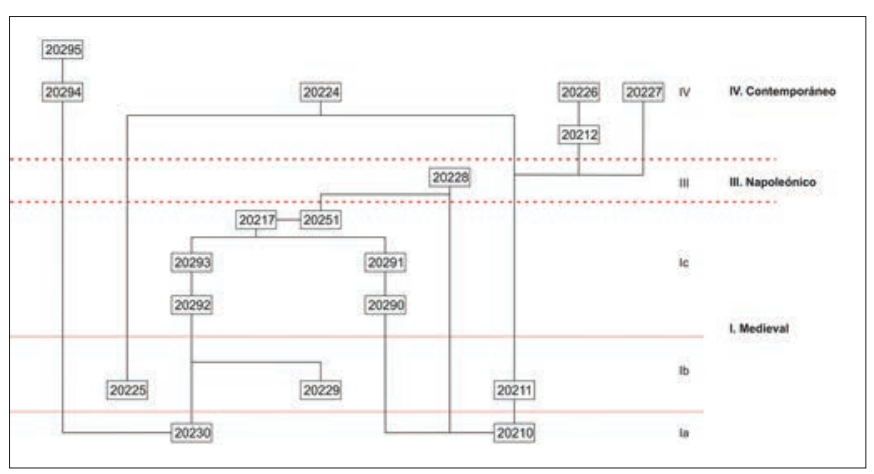

Figura 18. Matrix Harris de la E25.

En época napoleónica (III), el acceso es tapiado por la UE 228, que se derrumbó parcialmente en el año 2005. Por último, las reparaciones contemporáneas se adscriben al período IV.

\section{Estructura 26}

Se corresponde con la cara oeste de la torre-puerta. Se traba a la izquierda con la E23 y a la derecha con la E26 (Figs. 19 y 20). La secuencia se inicia con dos UEs (221 y 222) realizadas en tapial de calicanto, cuya fábrica es equivalente a la del resto del recinto exterior. La UE 221 se sitúa en el centro del paramento, cubierta por las UEs 218 y 219. Sus dimensiones son de $0,7 \mathrm{~m}$ por 0,7 . La UE 222 se encuentra en la parte inferior derecha de la torre, con 3,2 m de alto por 2,1 de ancho. Está muy afectada por procesos posteriores, mostrando restos de cemento y pintura amarilla. Se traba con la UE 230 de la E25. Probablemente su parte inferior esté excavada para crear las casas-cuevas contemporáneas, habiéndose perdido las zarpas de cimentación.

Posteriormente se construye el tapial calicostrado (Fig. 21) que se conserva en la esquina superior izquierda de este lienzo (UE 220). Aunque los enlucidos posteriores enmascaran su relación con las UEs 221 y 222, su fábrica es equivalente al resto del tapial calicostrado de la torre, por lo que seguramente se esté apoyando sobre el de calicanto. Se traba a su izquierda con la UE 175 y presenta de forma excepcional cuatro ladrillos en una junta entre cajones en su parte superior. Sus dimensiones son de 4,6 m de alto por 1,6 de ancho. 


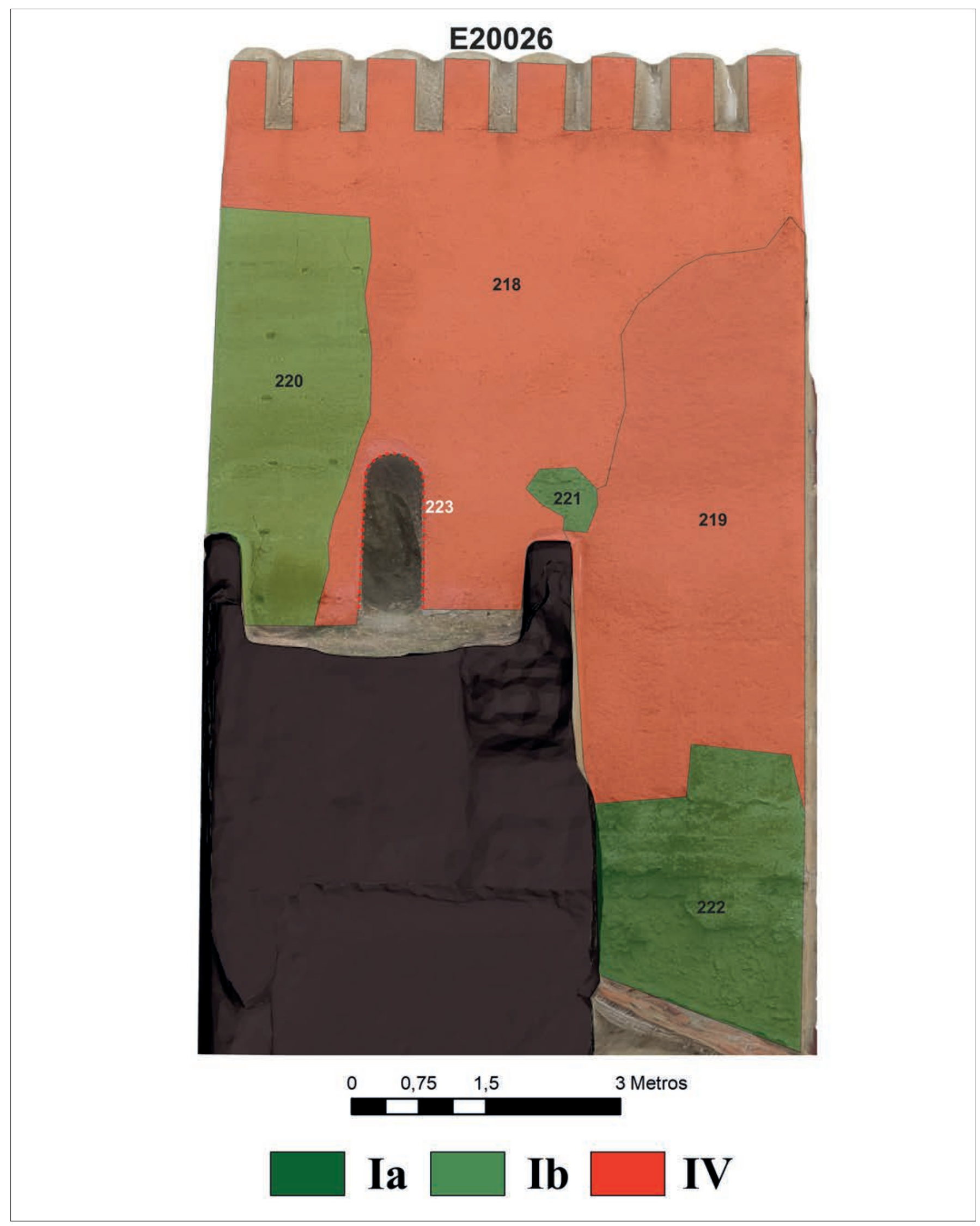

Figura 19. UEs y secuencia histórica de la E26. 


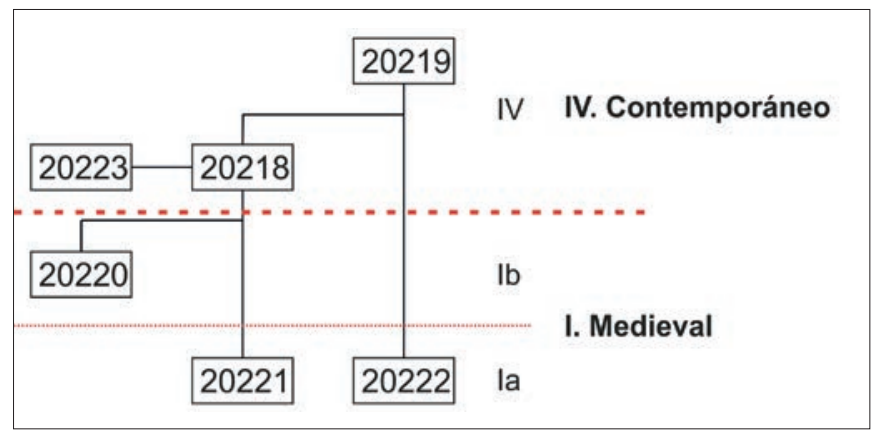

Figura 20. Matrix Harris de la E26.

Ya en época contemporánea, se reconstruye la parte superior del muro y la merlatura con mampostería irregular con cemento pintado de amarillo (UE 218). Tiene $6 \mathrm{~m}$ de altura máxima y de 3 a $6 \mathrm{~m}$ de anchura. En su parte inferior se dejó un vano en forma de arco de medio punto (UE 223) de 0,66 m de luz y $1,7 \mathrm{~m}$ de altura, que permite el paso a la parte superior de la torre-puerta. Por último, cubriendo al muro (UE 218) existe un enlucido de cemento posterior, la UE 219 (2,3 por $5,4 \mathrm{~m})$, que ocupa la parte derecha del lienzo y cubre también a su vez al tapial de calicanto (UEs 221 y 222).

Podemos, por tanto, dividir la secuencia constructiva en dos períodos: medieval (I) y contemporáneo (IV). El medieval se divide en dos fases: Ia y Ib. La Ia se corresponde con la torre de flanqueo de la puerta en tapial de calicanto de época zirí (s. XI), concretamente la oeste (UEs 221 y 222). En la fase Ib, del XII o ya del XIII, se recrece la torre con tapial calicostrado (UE 220). Finalmente, en época contemporánea (IV) se realizan las obras de restauración.

\section{Estructura 27}

Se trata del coronamiento superior de la torre-puerta (Figs. 22 y 23). Presenta un socavón en su parte occidental, donde se abre la puerta practicada en el siglo XX (UE 223 de la E26). Gracias a ello se puede acceder al resto de la terraza y la parte superior de la buhedera.

La secuencia se inicia con la UE 247, que se sitúa en la parte inferior y es visible gracias a la rotura en el tapial calicostrado que la cubre (UE 248). Se trata de un tapial de calicanto, equivalente al del resto del recinto exterior, que da cara hacia el interior de la torre y se encuentra alineada con la muralla CE 13. Por tanto, marca la línea original de las torres y su recrecimiento hacia el interior en la fase Ib (Fig. 24).

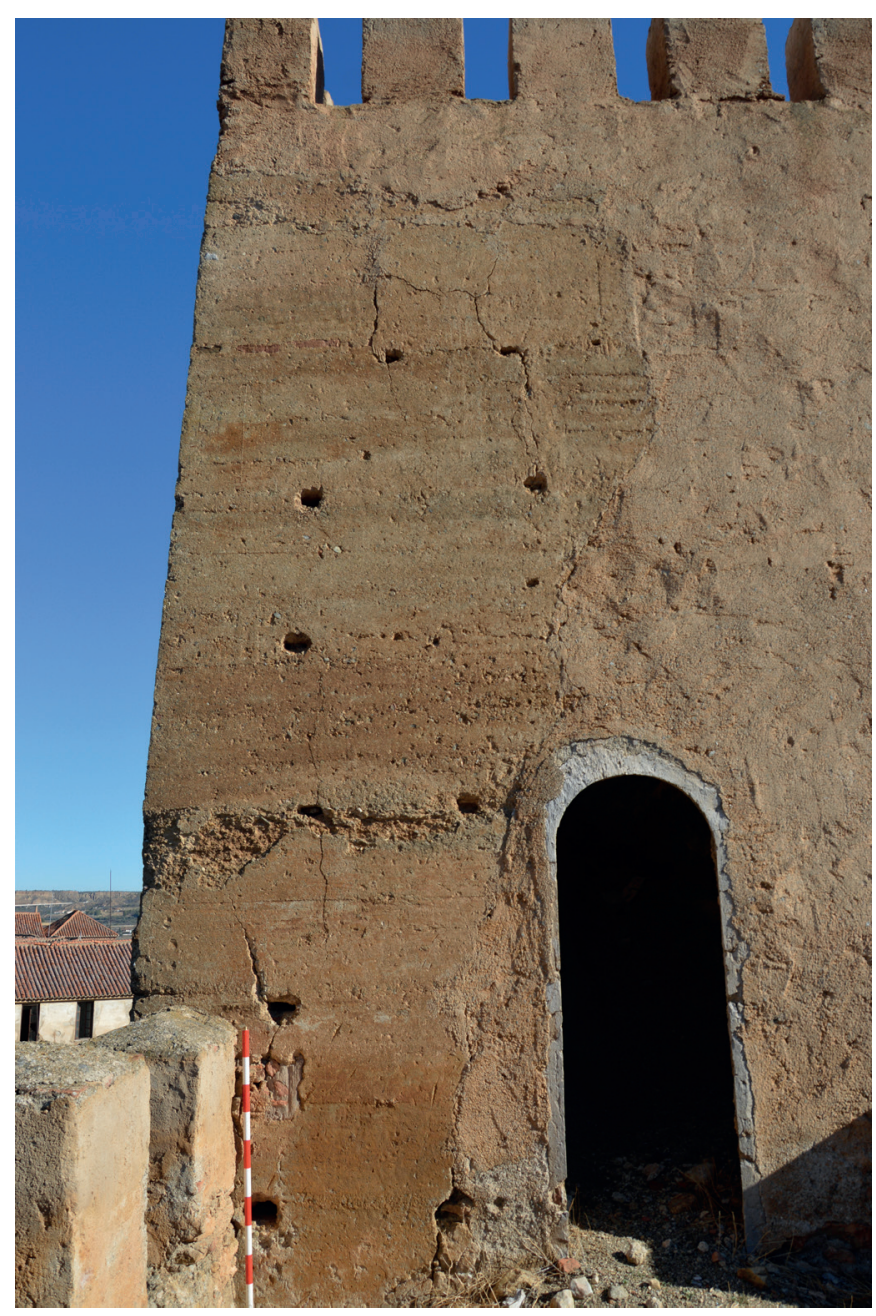

Figura 21. Tapial calicostrado (UE 220) de la fase Ib en la E26.

Posteriormente, sobre el tapial de calicanto (UE 247) se apoya el recrecimiento macizo de las dos torres y su engrosamiento hacia el interior (UE 248). Es un tapial calicostrado que forma en la parte superior una terraza sobre la que se levantan los pretiles originales (UEs 240, 241, 242, 243, 244, 245, 246). Estos están realizados en el mismo tipo de fábrica que la UE 248 y se extienden por todos los laterales excepto en el lado oeste, donde se ha reconstruido el paramento por completo. En el centro de la fachada sur siguen el flanqueo de las dos torres ziríes originales. Así, la UE 240 es el pretil suroeste, las UEs 241, 242 y 243 conforman el flanqueo, la UE 244 es el sureste, la 245 el este y la 246 el norte. El lado oeste no se conserva por la pérdida de masa en esa zona.

Posteriormente, se cierra el flanqueo de las torres con un muro (UE 250), que se apoya en las UEs 241 y 243 y se corresponde con la UE 217 descrita en la 


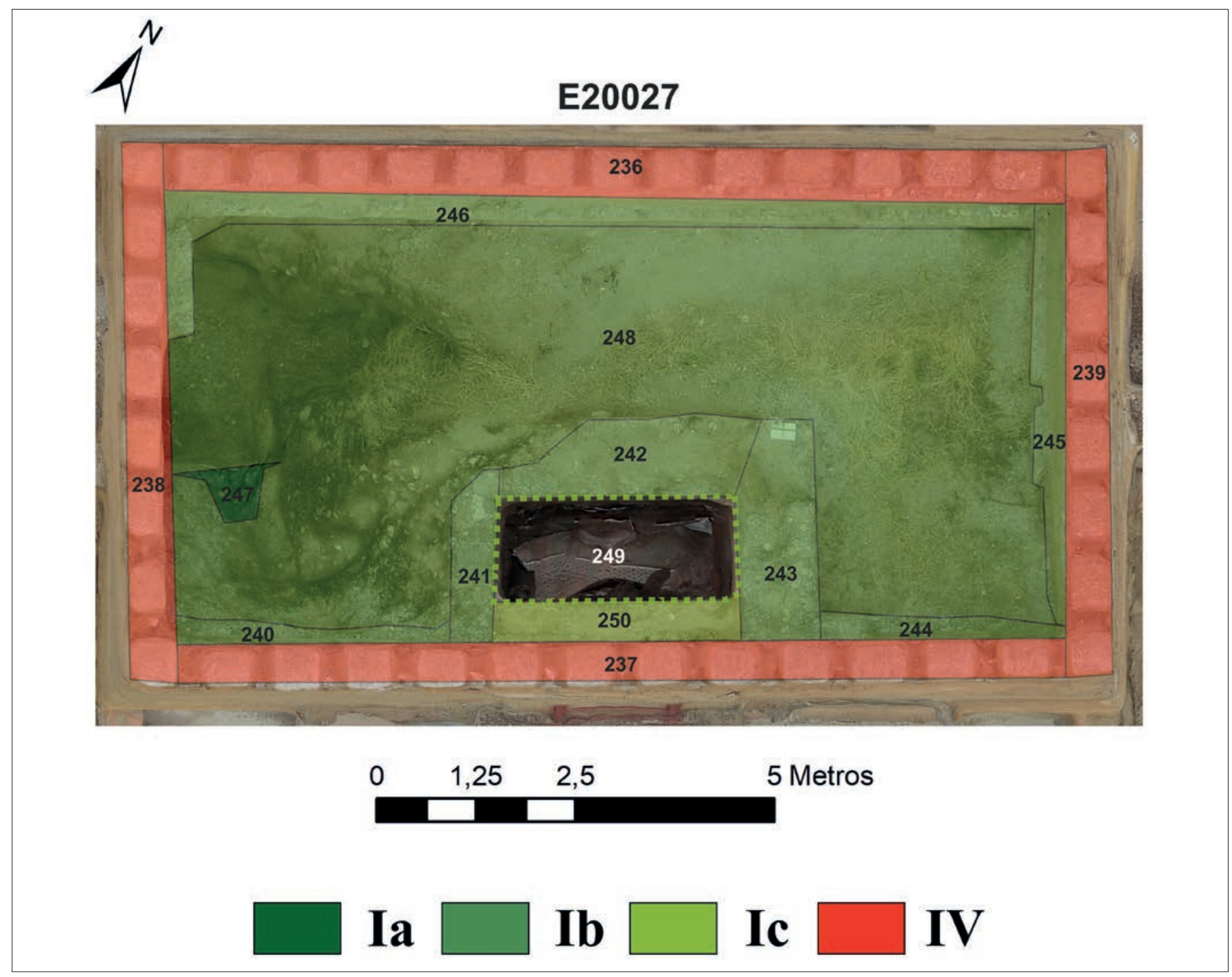

Figura 22. UEs y secuencia histórica de la E27.

E25. Como vimos, este muro cierra el espacio entre las dos torres generando una buhedera rectangular (UE 249, Fig. 25). Está construido en un tapial calicostrado corrido con módulo pequeño, pero al conservar su recubrimiento exterior no se pueden observar más características de su fábrica.

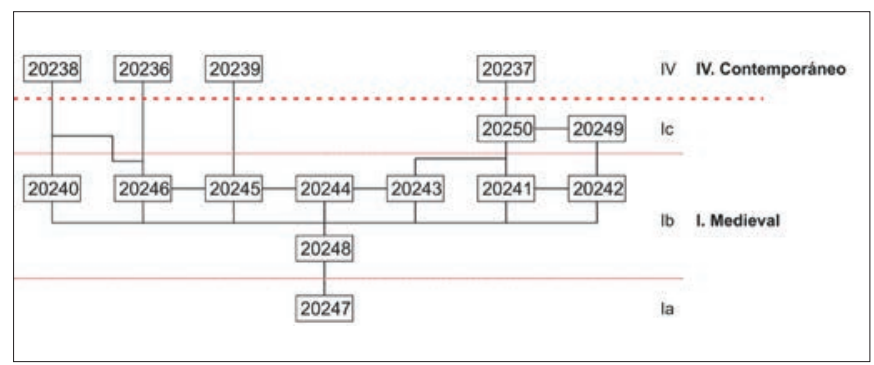

Figura 23. Matrix Harris de la E27.
Por último, sobre los restos del pretil y la terraza original se reconstruyen los pretiles y merlones con mampuestos y cemento. Así, la UE 238 cierra el lado oeste, apoyándose en la 240 y 246; la UE 237 el lado sur, sobre la 240, 244 y 250; la UE 239 se levanta en el este, sobre la 245 y, por último, la UE 236 se apoya en 246 en el lado norte.

Descrita la secuencia constructiva, esta puede dividirse en dos períodos: medieval (I), dividido a su vez en tres fases, y contemporáneo (IV). La fase Ia se corresponde con la etapa zirí, de la que se conserva solo la UE 247, que marca el arranque original de la torre oeste de la entrada. Concretamente se trata del contacto entre la muralla, más baja, y la torre, que tenía un cajón más de altura. A continuación, en Ib se recrece la torre en altura y hacia el interior de la alcazaba, superponiéndose a las estructuras 
anteriores con una fábrica de tapial calicostrado que incluye la terraza y el pretil (UEs 240, 241, 242, 243, 244, 245,246 y 248). El período medieval se cierra en Ic con la creación de la buhedera mediante un muro de tapial calicostrado que se apoya contra las dos torres (UEs 249 y 250). Por último, en el período IV se reconstruyen el muro occidental y los pretiles con materiales contemporáneos.

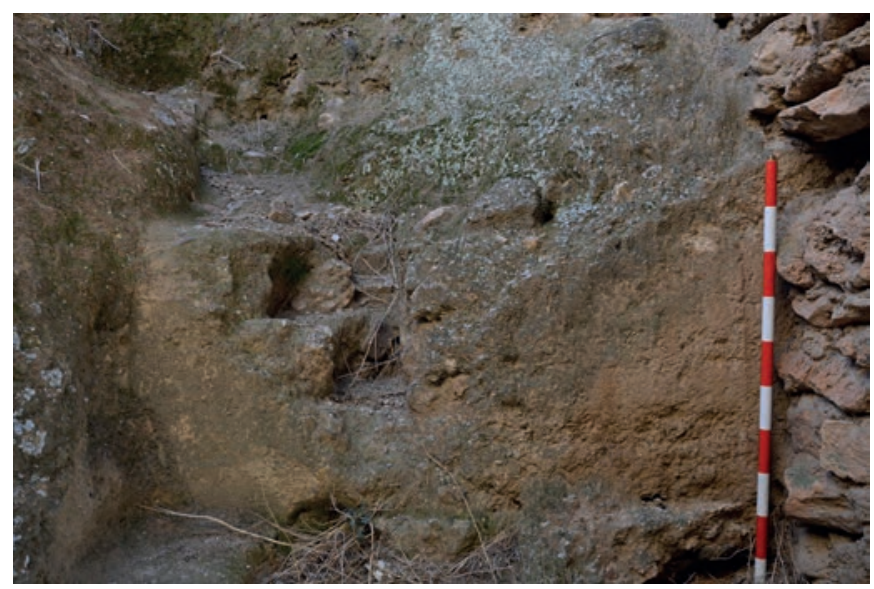

Figura 24. Tapial de calicanto (UE 247) de la fase Ia en la E27.

\section{Estructura 32}

Se trata de la cara oriental de la torre oeste, que quedó dentro del hueco de la buhedera. Se traba con la E33 a su izquierda (Fig. 26). La primera UE de la secuencia es la 271, un tapial de calicanto en cajones, que ocupa la mayor parte de este paramento. Se le apoya en su parte superior la UE 272, el tapial calicostrado. La junta entre 271 y 272 es cubierta por un parche de cal muy blanco con incisiones a espiga (UE 273).

Posteriormente se crea la buhedera. Por ello se realiza un corte horizontal (274). Esta unidad negativa es más estrecha hacia la parte interior del paramento. Se trata de una roza para el anclaje de los rollizos que sostienen el muro de cierre de la buhedera (UE 217). Su relleno está hecho en ladrillo unido con mortero de cal. En su base tiene una tabla horizontal que amortigua la carga (UE 303).

En época napoleónica se realiza un corte vertical (UE 275) en la parte inferior, con el objetivo de anclar la imposta de la bóveda que techará la puerta y ciega la buhedera. También aquí se apoyará en la UE 271 el muro que ciega el vano (UE 228).

La secuencia se divide en dos períodos: medieval (I) y napoleónico (III). El período medieval se subdivide a su vez en tres fases: la Ia se corresponde con la torre de entrada original del siglo XI en calicanto (UE 271); la Ib con el recrecido de calicostrado (272 y 273) y la Ic con la creación de la buhedera (UEs 274 y 303). Ya en el período napoleónico (III), se inserta la bóveda (UEs 274 y 303) que acondiciona el interior de la torre-puerta y ciega la buhedera y se construye el muro de cierre del acceso para transformar la entrada en una habitación.

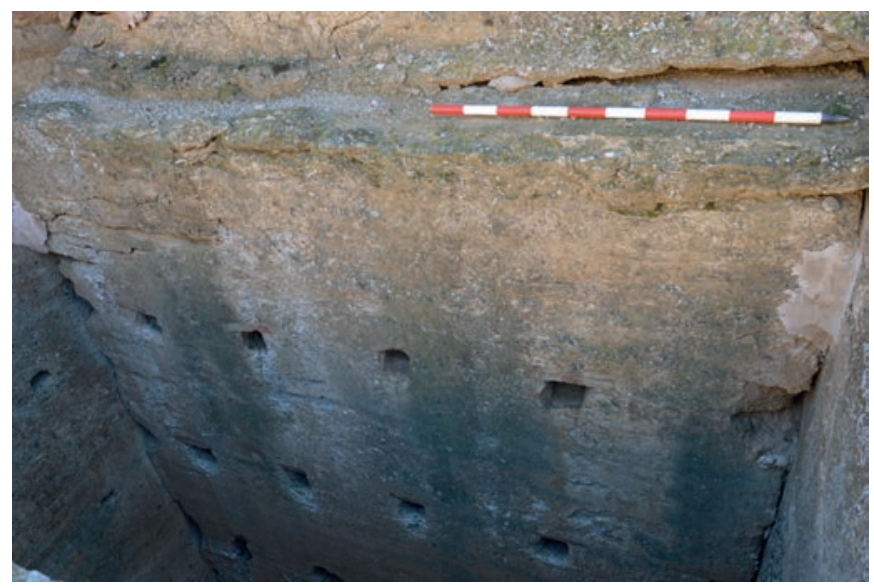

Figura 25. Parte superior de la buhedera (UE 250).

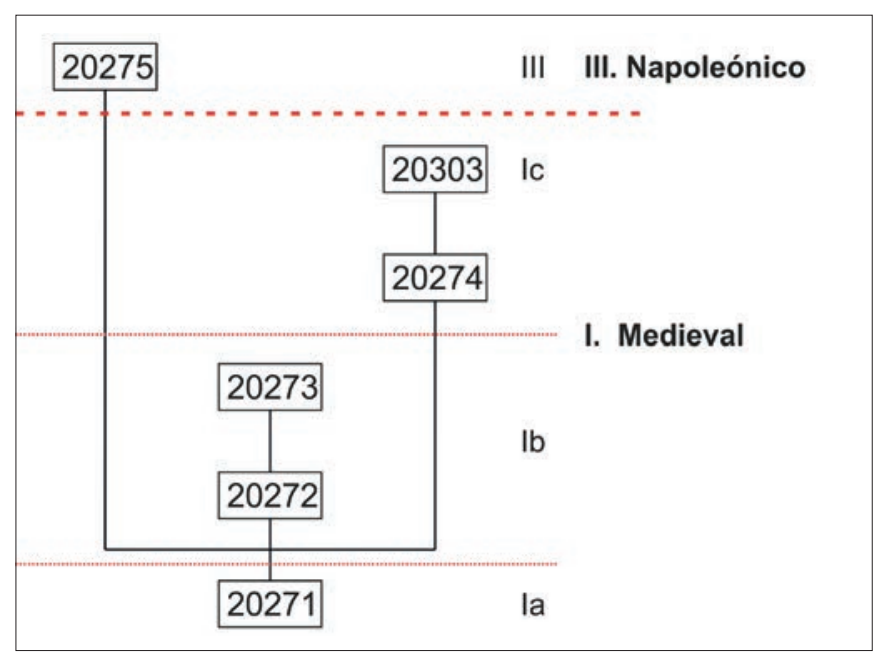

Figura 26. Matrix Harris de la E32.

\section{Estructura 33}

Es el antiguo frente de la muralla donde se abría la puerta original, situado entre las dos torres, y que posteriormente quedó como parte interna de la buhedera. Se traba a su derecha con la E32 y a la izquierda con la E34 (Fig. 27). La secuencia se inicia en época zirí con la UE 276. Su fábrica es de calicanto y está muy bien conservada. Sobre ella se apoya la UE 277, el recrecido de la torre en tapial calicostrado. Cubriendo las juntas hay un mortero de cal con incisiones a espiga (UE 278) equivalente a la UE 273. 
Posteriormente se realizan dos cortes rectangulares en la parte baja del muro, de pequeñas dimensiones (UEs 279 y 280). Su función es desconocida, pero por posición topográfica y estratigráfica podrían estar relacionadas con algún tipo de anclaje en relación con la buhedera. La UE 280 es rellenada por un parche de color grisáceo (UE 281), pero la imposibilidad de acercarse a ella impide conocer el material con el que está realizado.

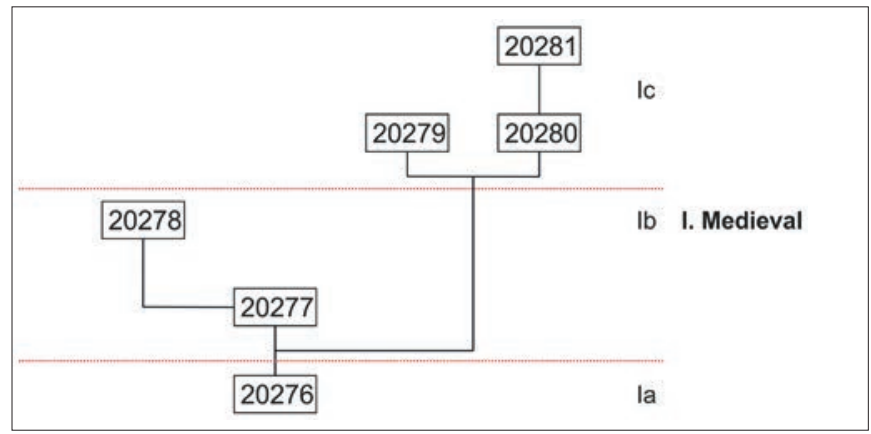

Figura 27. Matrix Harris de la E33.

Su cronología es únicamente de época medieval (I), pero dividida en tres fases: encontramos la Ia, que se corresponde con el lienzo de muralla de calicanto (UE 276) original del siglo XI y que forma el frontal de la puerta. En la fase $\mathrm{Ib}$ se recrece el paramento con tapial calicostrado (UEs 277 y 278) y, por último, en Ic se producen algunas modificaciones menores probablemente por la creación de la buhedera (UEs 279 y 280).

\section{Estructura 34}

Se trata de la cara oeste de la torre oriental, que quedó dentro del hueco de la buhedera. Se traba a la derecha con la E33. La historia constructiva de esta E (Fig. 28) se inicia con la UE 282, que ocupa el centro del paramento. Al igual que en el resto del CE se corresponde con la fábrica original de calicanto. De nuevo se le apoya el tapial calicostrado que recrece la torre (UE 285). Posteriormente se realiza un corte horizontal (283) en la fábrica de calicanto, equivalente a la UE 274 y situada en frente. La UE 283 es rellenada por la 284, anclaje para los rollizos que soportan el muro de cierre de la buhedera (UE 217), y que a su vez es equivalente a la UE 303. En este caso el parche está parcialmente enlucido con incisiones a espiga, pero oculto en parte por la propia UE 217. Por último, se realiza el corte vertical 286 en la parte baja del paramento, equivalente a la UE 275, que sirve de anclaje para la bóveda napoleónica.

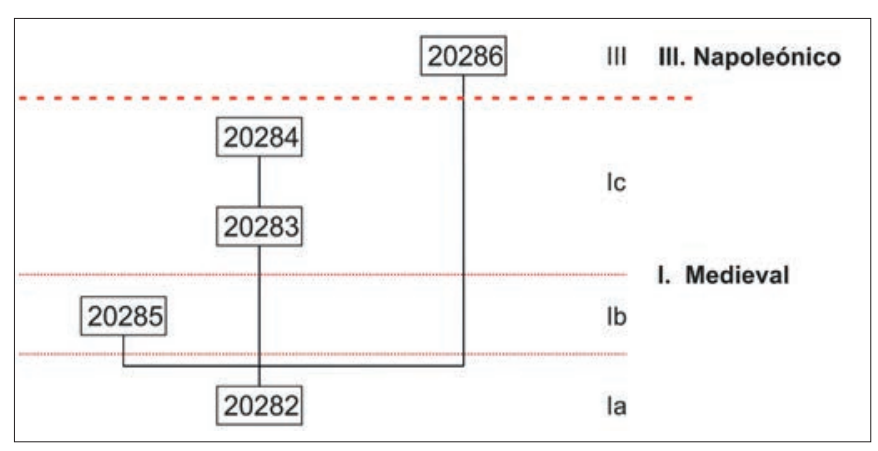

Figura 28. Matrix Harris de la E34.

$\mathrm{Su}$ secuencia es idéntica a la E32, con un período medieval (I) dividido en tres fases y otro de época napoleónica (III). La primera fase medieval Ia es como siempre la compuesta por la torre original este del ingreso zirí a la alcazaba (UE 282). Esta, como sabemos, es recrecida en la fase Ib con el tapial calicostrado (UE 285). Posteriormente, se abren los huecos para recibir las sujeciones del muro de cierre de la buhedera (UEs 283 y 284). Finalmente, en el período III se inserta el apoyo de la bóveda de las tropas francesas (UE 286).

\section{Estructura 35}

Esta estructura es la bóveda de cañón que cubre el interior del acceso y que fue construida en época napoleónica. Se apoya como hemos visto en los muros de las torres de flanqueo (E32 y E34, Fig. 29), de manera que ciega la buhedera para transformar el antiguo acceso en una habitación. La bóveda (UE 288) se ancla en los cortes de las UEs 275 (en la E32) y 286 (en la E34). Está construida con una vuelta de ladrillo de media rosca que cubre todo el espacio interior de la puerta y cerraba la buhedera, pero sin soportar carga alguna. El extremo sur se derrumbó en el año 2005 cuando cedieron los rollizos de la UE 217. Está hecha con ladrillo reutilizado y mortero de cal. En su interior está cubierta por un mortero blanco (UE 287), igual al que enluce las paredes interiores de la puerta, aunque está ennegrecido. Sobre su trasdós se ha formado una acumulación natural de tierra y fragmentos de ladrillo y mortero por el deterioro y derrumbe paulatino de las estructuras superiores (UE 289). 


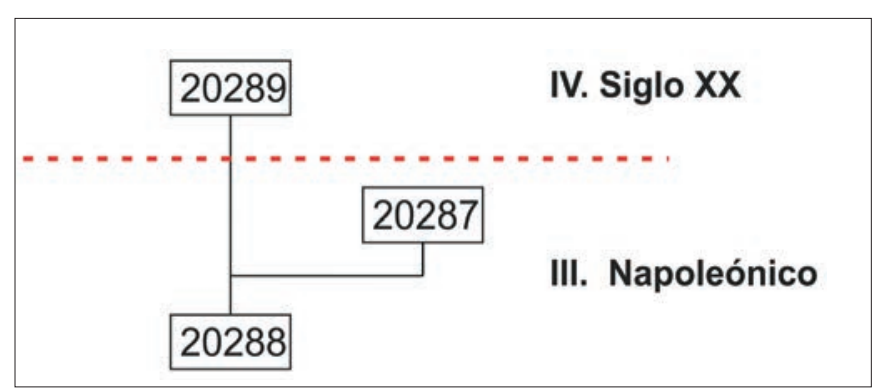

Figura 29. Matrix Harris de la E35.

Su secuencia se divide en dos períodos, el napoleónico (III) y el contemporáneo (IV). El primero se corresponde con la bóveda y su enlucido (UEs 287 y 288) y el segundo con la acumulación que se ha producido en su trasdós (UE 289).

\section{Estructura 36}

Se corresponde con la pared este del pasaje interior de la puerta. El enlucido hace que parezca trabada a la bóveda E35 (Figs. 30 y 31).
La secuencia se inicia con los restos del arco original de época zirí situado en la parte inferior derecha del paramento (UE 258). Está realizado con sillería de piedra arenisca, muy deteriorada, y mortero de cal muy blanco (Fig. 32). A pesar del desperfecto es bien visible el aparejo a soga y tizón de los sillares, que son piezas reutilizadas y retalladas del antiguo teatro romano de la ciudad como ocurre en otras zonas de la alcazaba y de la muralla de la medina. Está en fase con el tapial (UE 259), aunque no se aprecia si se traba o se apoya a este. La UE 259 es el muro original de la puerta realizado en tapial de calicanto equivalente al del resto de la torre. Presenta cara en la parte izquierda de la UE. Una fisura vertical que atraviesa toda la estructura y que se corresponde con la junta entre el tapial de calicanto de la muralla original y el añadido en tapial calicostrado que hemos documentado en el resto del complejo.

Posteriormente, se construye la puerta interior, cuya jamba izquierda es la UE 306. Está realizada con un aparejo a soga y tizón con medio ladrillo en la soga, que tiene una medida de $28 \times 3 \mathrm{~cm}$. Apoyándose en las UEs

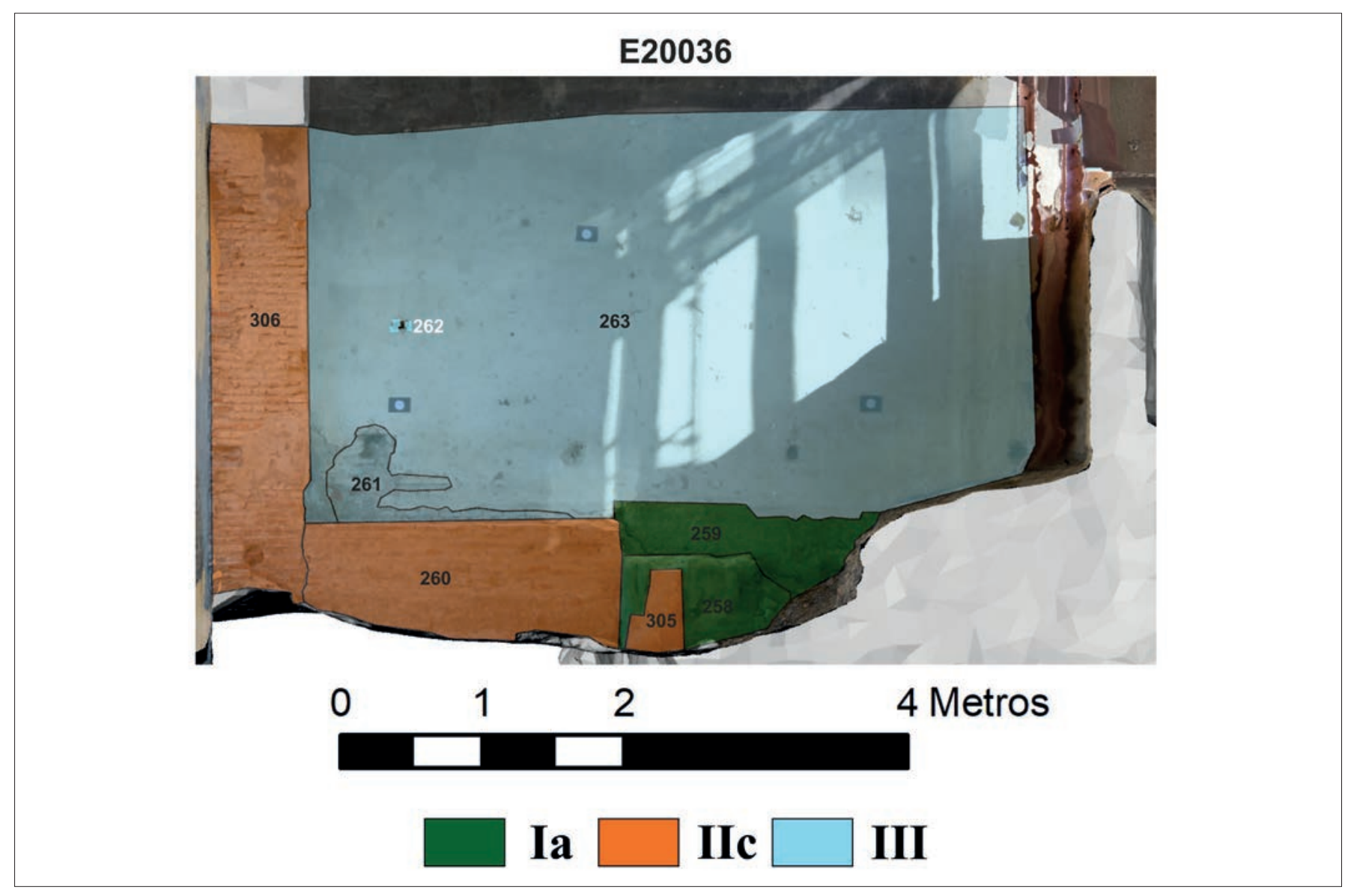

Figura 30. UEs y secuencia histórica de la E36. 
258, 259 y 306 está la UE 260. Se trata de un cierre para estrechar la puerta realizado en mortero gris y ladrillo, situado en la parte baja del paramento. Las dimensiones de las sogas son $27 / 28 \mathrm{~cm}$ de largo por $3 / 3,5 / 4 \mathrm{~cm}$ de ancho. También en este momento, cubriendo a la UE 258 aparece la UE 305, un parche con ladrillo macizo y mortero grisáceo que da cara.

Finalmente, seguramente de época napoleónica en conjunción con la bóveda, sobre la UE 260 se apoya la UE 261. Se trata de un muro con ladrillo macizo reutilizado y mortero gris que es visible en el centro del paramento. En esta fase se abre un mechinal, la UE 262. Tanto 261 como 262 son cubiertas por la UE 263, un enlucido de mortero de color blanquecino que reviste toda la pared, igual al que cubre la bóveda (UE 287).

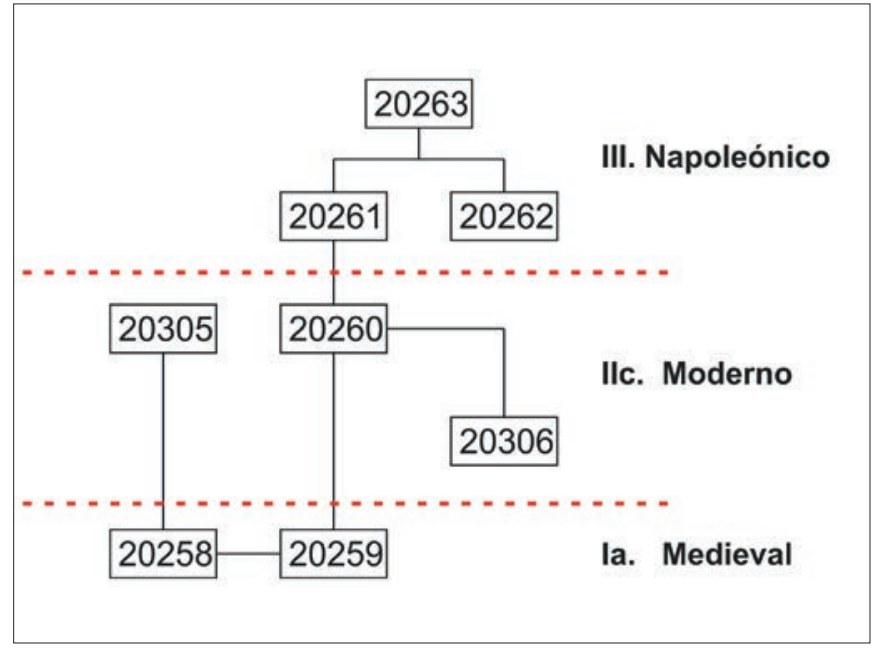

Figura 31. Matrix Harris de la E36.

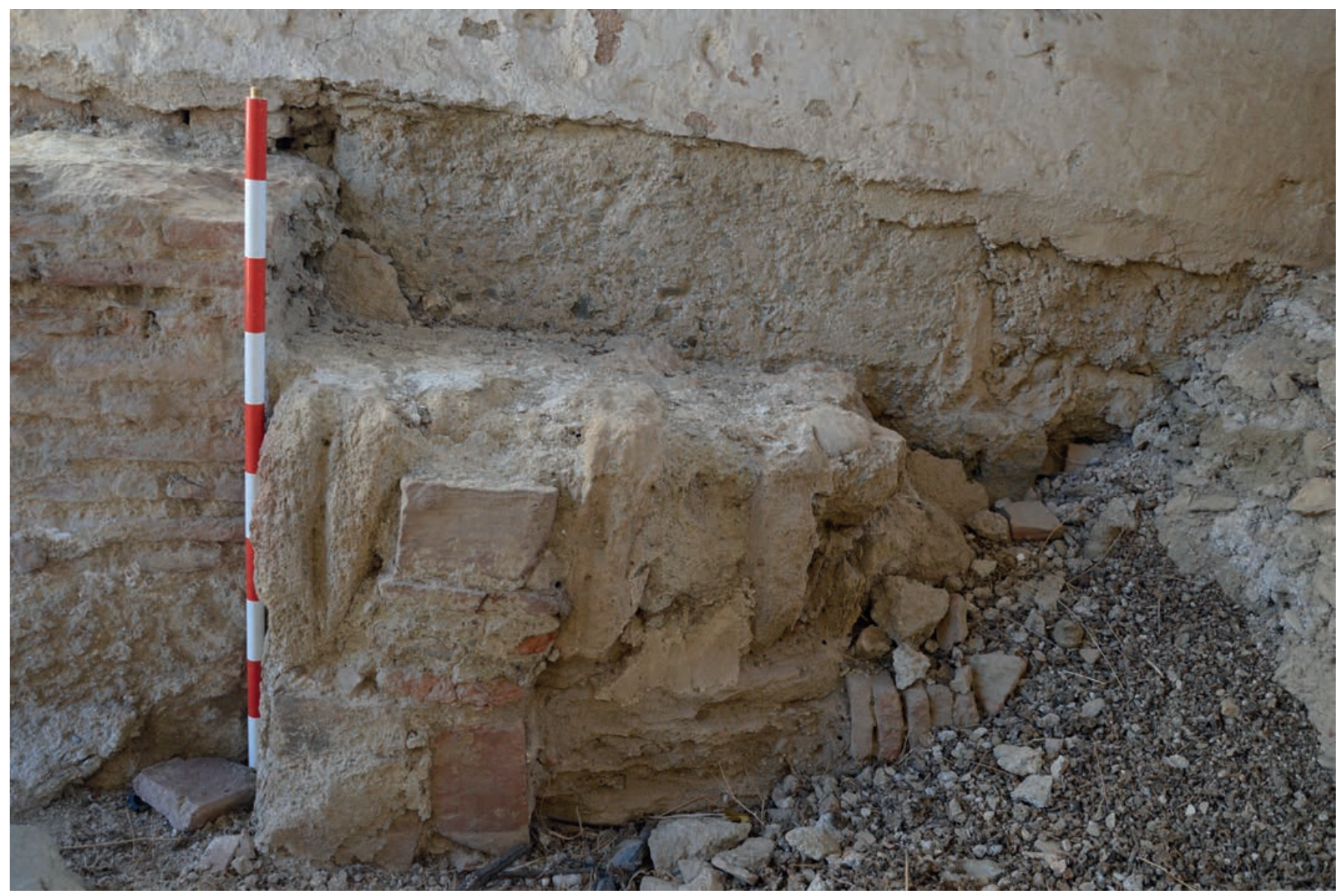

Figura 32. Restos del arranque de la puerta (UE 258) en sillería de época zirí. 


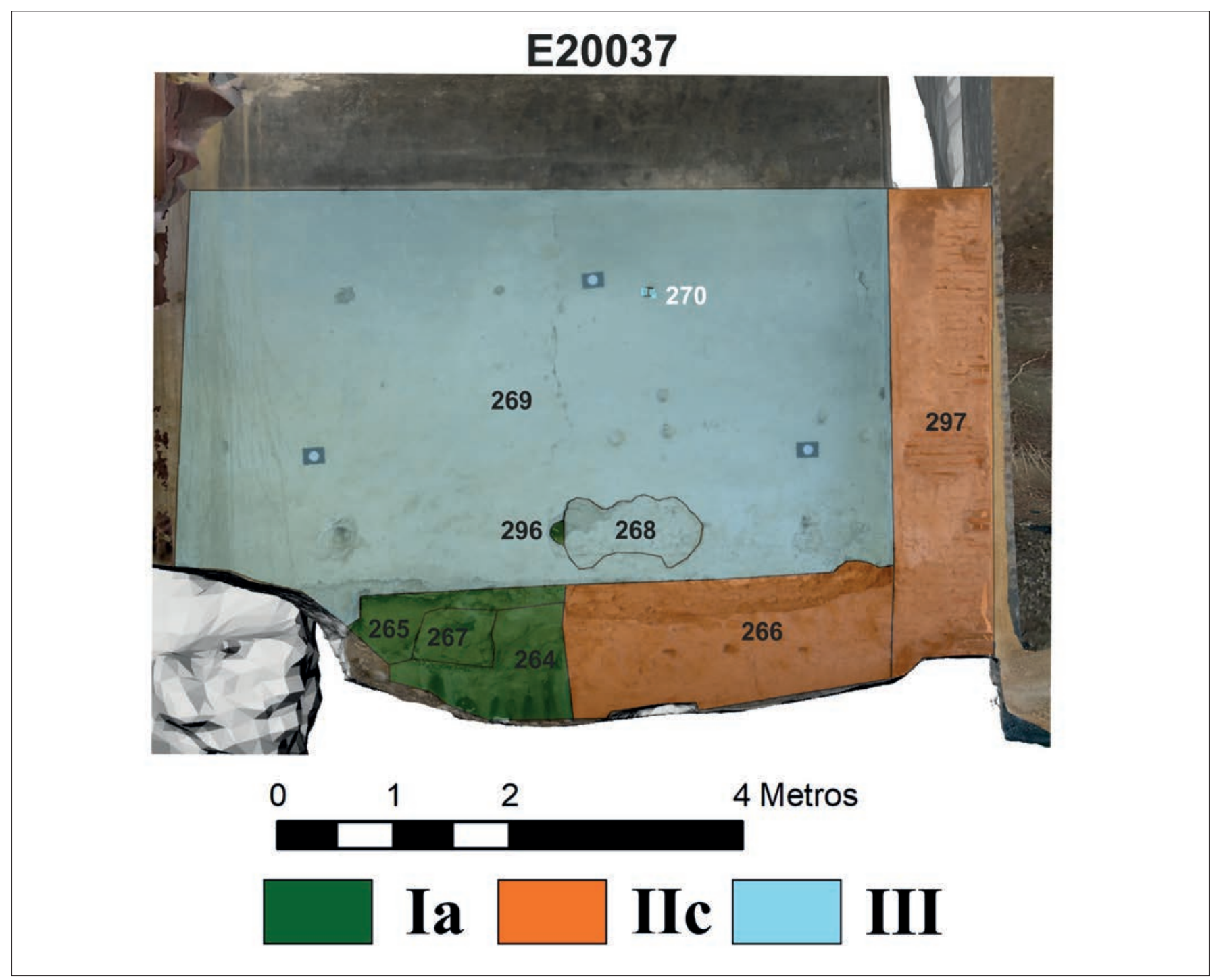

Figura 33. UEs y secuencia histórica de la E37.

Podemos, por tanto, dividir su secuencia en tres períodos: medieval (I), moderno (II) y napoleónica (III). Del período medieval (Ia) datan los restos de la puerta original de sillería (UE 258), formando seguramente un arco de herradura, y el tapial original de la cara interior de la torre (UE 259), realizado en calicanto. El enlucido no permite observar el tapial calicostrado que hemos documentado como engrosamiento y recrecimiento de todo el complejo en la fase $\mathrm{Ib}$, pero es claramente visible a través de la grieta abierta en la junta entre las dos fábricas y coincide en la planta y en el levantamiento tridimensional. Posteriormente, tras la conquista castellana (IIc) se añadirá la puerta interior a la alcazaba y se estrecha el acceso (UEs 306 y 260). De este momento data probablemente también el parche (UE 305) que arregla el arco zirí, por lo que este seguiría todavía en funcionamiento. La secuencia finaliza con la reconversión del acceso en una estancia en el período napoleónico (III), con la construcción del muro de ladrillo reutilizado y el enlucido (UEs 261 y 263), que se traba con la bóveda que techa el espacio.

\section{Estructura 37}

Es el muro oeste de la puerta de entrada, situado frente a la E37. Su enlucido traba también con la bóveda napoleónica (E35) y cubre las fábricas originales. Se inicia la secuencia (Figs. 33 y 34) con la construcción de la puerta zirí en la esquina inferior izquierda. En este caso, además de los sillares (UE 264), se puede observar el relleno del arco (267) tras ellos, realizado con mampuestos y un mortero blanco idéntico al de la UE 264. Trabada 
con los dos elementos de la puerta, tenemos el tapial de calicanto (UE 265). Más arriba, un desconchón del enlucido deja ver otro fragmento de tapial equivalente (UE 296). Hacia el lado norte se observa cómo da cara, coincidiendo con la fisura vertical que marca el contacto entre la primera línea de muralla y el recrecimiento de tapial calicostrado que se le adosa, igual que en la E36.

Posteriormente, se añade la jamba de la ampliación de la puerta hacia el interior (UE 297), equivalente a la UE 303 de la E36. Apoyándose en ella y en el arco de la puerta (UE 264) tenemos a la UE 266. Se trata de una UE que estrecha la parte trasera del acceso. Está realizado en un tapial calicostrado con una costra rica en cal $(30 \mathrm{~cm})$. Se observa su relleno de tierra, en el que se incluye ladrillo y con cantos y conserva tres mechinales.

Finalmente se construye un muro (UE 268) que completa la estructura y que se aprecia solo a través de un desconchón. Está realizado en un aparejo mixto compuesto de hiladas simples de ladrillo macizo con mampuestos unidos por un mortero que no se aprecia por el enlucido que lo recubre. Esta última UE (269) cubre tanto a las UEs 266 y 268 como a la 265 y 296. Este enlucido es cortado por la UE 270, un mechinal de función indeterminada.

$\mathrm{Su}$ secuencia es idéntica a la de la E36. La fase Ia se corresponde con el arco de entrada del siglo XI (UEs 264 y 267), junto con el tapial de calicanto de la torre este (UE 265). Al igual que en el paramento frontero, no es visible la fase en tapial calicostrado (Ib) debido al enlucido que recubre toda la pared, pero la fisura vertical en la junta de las dos fábricas y el levantamiento realizado permiten su identificación, aunque no su documentación en la secuencia. Ya tras la conquista castellana (IIc), se crea la puerta interior (UE 297) y se estrecha el acceso, en este caso con un tapial calicostrado (UE 266) que se apoya contra la jamba. Dada la diferencia de técnica constructiva con la UE 260 de la E36, deben ser de momentos espaciados en el tiempo. No obstante, cumplen una función similar y su adscripción cronológica debería de ser la misma. Esta, sin duda, es la parte más compleja de interpretar desde el punto de vista de la secuencia y la funcionalidad y plantea interrogantes que esperamos pudieran resolverse a lo largo de una intervención de restauración. Por último, en el período napoleónico (III), se crea el muro (UE 268) que probablemente sostiene la bóveda y todo el paramento fue enlucido (UE 269) junto con la bóveda y el muro de enfrente para acondicionar el espacio como habitación.

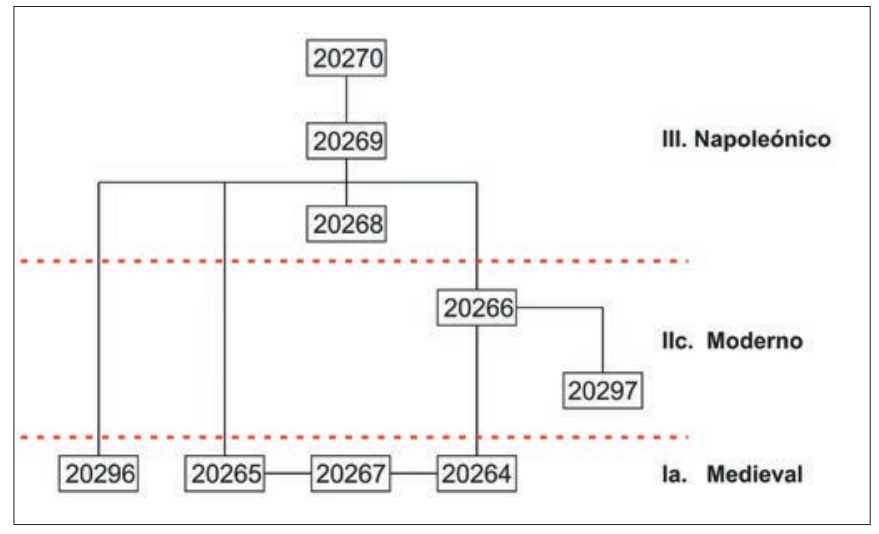

Figura 34. Matrix Harris de la E36.

\section{CONCLUSIONES}

La evolución de las estructuras de la torre-puerta es, como hemos visto, tan compleja como interesante. Esto la convierte una pieza muy valiosa no solo por su importancia patrimonial, sino porque su secuencia es fundamental para entender el conjunto de la alcazaba (Fig. 35).

La historia de este acceso se inicia en el período medieval (I), que se subdivide en tres fases. La primera fase (Ia) supone la construcción de una puerta en forma de arco, seguramente de herradura (Sarr y Reyes 2006), flanqueado por dos torres macizas de tapial de calicanto en cajones trabadas al resto del recinto exterior (Es 29 y 30 ), realizado originalmente con la misma técnica constructiva. Sería pues, un acceso en eje directo similar al documentado en la puerta norte de la alcazaba en las excavaciones, también seguramente con una rampa de acceso para salvar el desnivel existente (Martín Civantos 2010a: 54-55). Se correspondería pues con el esquema de puerta tripartito descrito por Pavón (1999: 391-403), clásico en al-Ándalus hasta la introducción de las puertas en recodo. Como hemos aludido ya en la descripción de la secuencia, atribuimos esta fase al siglo XI, en época de la dinastía zirí. La muralla de tapial de calicanto fue fechada en ese momento en las excavaciones de 2009 (Martín Civantos 2010a: 50-55). Entonces, se pudo documentar una fosa amortizada con materiales del siglo X sobre la que se construyó una de las torres. Además, esta técnica ha sido identificada para el caso granadino como parte de un programa constructivo estatal zirí (Martín Civantos 2008 y 2009), cuya existencia ha ido confirmándose en intervenciones arqueológicas posteriores (Malpica et al. 2015: 302-307). 
En época almohade o nazarí, entre los siglos XIIXIII (Ib), se produce la mayor reforma del complejo. Se recrecen las torres en altura, como es visible en las cuatro caras exteriores, pero también se engrosa la estructura hacia el interior del recinto, hasta prácticamente el doble del tamaño de las torres y englobando la muralla original. La obra se realiza en tapial calicostrado, tipología constructiva cuyo origen está datado a partir del siglo XII (Martín García y Martín Civantos 2009). Este recrecimiento y engrosamiento puede verse muy bien en el lateral este (E24) y en la terraza, concretamente en la UE 247. No podemos saber si los lienzos que se trababan con la torre-puerta sufrieron reformas en este momento, puesto que el CE 13 se encuentra totalmente enmascarado por las restauraciones del siglo XX y el CE 15 fue sustituido por la creación de una nueva puerta en época napoleónica, que fue derribada en el año 2007.

\begin{tabular}{|c|c|c|c|c|}
\hline \multicolumn{5}{|c|}{ Evolución constructiva de la torre-puerta } \\
\hline Fase & Cronología & Es & UES & Técnica constructiva \\
\hline la & 5. XI & $\begin{array}{l}24 \\
25 \\
26 \\
27 \\
32 \\
33 \\
34 \\
36 \\
37 \\
\end{array}$ & \begin{tabular}{|l}
201 \\
210,230 \\
221,222 \\
247 \\
271 \\
276 \\
282 \\
258,259 \\
$264,265,267,296$ \\
\end{tabular} & $\begin{array}{l}\text { Tapial de cal y canto } \\
\text { silleria }\end{array}$ \\
\hline lb & 29 1/2 s. XII-s. XIII & $\begin{array}{l}23 \\
24 \\
25 \\
26 \\
27 \\
32 \\
33 \\
34\end{array}$ & $\begin{array}{l}175,183,187 \\
200 \\
211,225,229 \\
220 \\
240,241,242,243,244,245,246,248 \\
272,273 \\
277,278 \\
285\end{array}$ & Tapial calicostrado \\
\hline Ic & s. XV & $\begin{array}{l}25 \\
27 \\
32 \\
33 \\
34 \\
\end{array}$ & $\begin{array}{l}217,251,290,291,292,293 \\
249,250 \\
274,303 \\
279,280,281 \\
283,284\end{array}$ & $\begin{array}{l}\text { Tapial calicostrado } \\
\text { Rollizos }\end{array}$ \\
\hline 110 & ss. XV-XVI & $\begin{array}{l}23 \\
24\end{array}$ & $\begin{array}{l}176,177,179,181,186,196,197,198 \\
204,205,209\end{array}$ & Aparejo inglés \\
\hline $11 b$ & s. XVI & 23 & $184,189,190,216$ & $\begin{array}{l}\text { Aparejo irregular } \\
\text { de ladrillo }\end{array}$ \\
\hline uc & 5s. XVI-XVII & $\begin{array}{l}23 \\
24 \\
36 \\
37\end{array}$ & $\begin{array}{l}178,191,193,213 \\
202,206,207,214,215 \\
260,305,306 \\
266,297\end{array}$ & $\begin{array}{c}\text { Aparejo irregular } \\
\text { de ladrillo } \\
\text { Tapial calicostrado }\end{array}$ \\
\hline It! & 5. XIX & $\begin{array}{l}23 \\
25 \\
32 \\
34 \\
35 \\
36 \\
36 \\
37\end{array}$ & $\begin{array}{l}192,194,195 \\
228 \\
275 \\
286 \\
287,288 \\
261,262,263 \\
268,269,270\end{array}$ & $\begin{array}{l}\text { Aparejo irregular } \\
\text { de ladrillo }\end{array}$ \\
\hline IN & s. $x x$ & $\begin{array}{l}23 \\
24 \\
25 \\
26 \\
27 \\
35\end{array}$ & $\begin{array}{l}174,180,182,185,188 \\
199,203,208 \\
212,224,226,227,294,295 \\
218,219,223 \\
236,237,238,239 \\
289\end{array}$ & $\begin{array}{c}\text { Cemento } \\
\text { Material reutilizado }\end{array}$ \\
\hline
\end{tabular}

Figura 35. Resumen de la secuencia constructiva de la torre-puerta.

En cualquier caso, con la adición de este nuevo cuerpo en la parte superior e interior, el acceso se ve en parte modificado, alargándose su pasaje en dirección norte (Fig. 36). Sin embargo, aparentemente no se transforma en una puerta en recodo y el aspecto externo teóricamente debería haber seguido siendo el de un acceso directo por el mismo arco de herradura flanqueado por dos torres ahora más altas.

Esto plantea un nuevo problema, ya que la reforma debería haber supuesto teóricamente la creación de un acceso en recodo. Así ocurre en la puerta norte excavada en 2009 (Martín Civantos 2010a: 54-55). En ese caso, lo que se hizo fue añadir en la parte delantera un nuevo cuerpo en forma de bastión donde se desarrollaba una rampa en recodo y, probablemente otra puerta adelantada. En la torre-puerta no es posible apreciar algo así. Aunque hubiera existido, la excavación de las cuevas en el siglo XIX hizo que se eliminara el terraplén, a lo que se añadió posteriormente la casa que actualmente se sitúa frente a la torre-puerta. Sin embargo, la presencia de la barbacana inmediatamente al suroeste hace suponer que debió de existir un acceso en rampa que habría forzado el recodo y que sería flanqueada por la última de las torres de esta doble muralla. Efectivamente, esta torre está construida también en tapial calicostrado y, por tanto, podría estar en fase con la reforma de la puerta (Rouco 2017: 185-191).

Se produce así una monumentalización de los ingresos a la alcazaba, en paralelo con la construcción del recinto interior en la que se documenta una probable función palaciega a partir de los restos encontrados en la intervención de 1986 (Raya 1987; Rouco 2017: 191192). Este fenómeno se documenta en otras fortalezas del reino nazarí, complicándose el acceso y segregándose aún más este espacio frente al resto del conjunto de la población de ciudades y villas. Estas modificaciones se han interpretado en el marco de las nuevas funciones y poderes de los alcaides de final de época almohade y nazaríes, que actúan como delegados del poder central (García 2016: 240-242). Este hecho concuerda con la amplia jurisdicción, ya mencionada, que poseían los alcaides de Guadix sobre los de las fortalezas dependientes de la medina (Trillo 2007: 283). Se remarcarían así mediante la arquitectura los espacios de poder del emirato.

No obstante, esta reforma produce un problema de integración entre la torre-puerta y el perímetro de murallas exterior. Al aumentarse la altura del CE en casi $5 \mathrm{~m}$, se corta el acceso a nivel a la parte superior de las dos antiguas torres que flanqueaban la entrada. Esto dificultaría la circulación rápida de los defensores por el recinto en caso de un ataque. Es algo que carece 
de lógica en comparación con otras torre-puertas realmente proyectadas como tales en época almohade o nazarí. Éstas aparecen dotadas de un cuerpo de guardia en la parte superior conectada con el paso de ronda de la muralla, como la torre-puerta de la fortaleza de Moclín (García 2015) o la Puerta de la Justicia de la Alhambra. Nos resulta imposible, además, conocer la manera en la que se accedería en este momento a la terraza de la torre, lo que tenía que ser posible por fuerza teniendo en cuenta que posteriormente se construyó una buhedera. No se conservan restos que indiquen la existencia de una escalera en el exterior de la torre ni en el interior, aunque quizás estuviese en el lado oeste actualmente roto (E27). Sin embargo, esto no permitiría la circulación desde la torre hacia el este. Quizás por esto se añadiese la torre oriental de la barbacana, para compensar la pérdida de integración defensiva de la puerta.

La última fase medieval (Ic), debería de corresponderse con el período nazarí. Es en este momento cuando se cierra el flanqueo de la puerta con un tapial calicostrado (UE 217) apoyado sobre rollizos, creando una buhedera. El aspecto precario que le confieren los maderos hace presuponer una cierta celeridad a la hora de ejecutar la reforma, como una solución temporal para aumentar la defensa del acceso. Es en este momento cuando el ingreso adquiere el aspecto macizo que hará que se lo denomine torre-puerta.

Tras la conquista castellana de Guadix, en 1489, se realizan pocas reformas en la alcazaba (período II). Básicamente se concentran en la torre-puerta, conformando su fase IIa. Se trata del refuerzo estructural de las caras norte y este realizado en ladrillo con aparejo inglés. Son paramentos ataludados construidos debido seguramente a problemas de cimentación de la torre o para la colocación de alguna batería artillera en la parte superior.

La fase IIb supone la reforma de la puerta interior, realizada en ladrillo, de manera que no se conservan vestigios del acceso en época nazarí. En la fase IIc, el pasaje se va estrechando paulatinamente y el tranco aumenta en cota (UEs 191 y 193), probablemente debido a una modificación en el nivel de uso del interior. En este momento también se producen cambios en el interior de la torre, constriñéndose el espacio de acceso entre el arco original zirí, que aún estaba en funcionamiento (como demuestra la UE 305, que lo repara) mediante las UEs 260 de la E36 y 266 de la E37. Estas UEs restringen el acceso, aunque está realizada una en ladrillo y otra en tapial y por tanto en dos momentos diferentes. Esto nos lleva a suponer que una vez traspasado el arco zirí, existirían dos huecos en las paredes de ambos lados. Podría tratarse de dos cuerpos de guardia o quizás alguno de ellos forzase la entrada en un pequeño recodo, pero resulta difícil de interpretar dado el poco espacio disponible para cualquiera de las dos funciones propuestas.

Ya en el III periodo, las tropas napoleónicas acondicionan el interior de la torre-puerta para utilizarlo como una estancia. Se ciega la puerta exterior construyendo un muro (UE 228) que enrasa el de la buhedera, techando el espacio con una bóveda corrida y enluciendo todo el interior. Aumenta además en altura el tranco de la puerta hacia el exterior (UEs 192, 194 y 195). Se convierte así en un espacio con una funcionalidad diferente. La datación de este período se realiza no solo por apoyarse en la castellana, sino también por las características de las fábricas, realizadas con material reutilizado y con un mortero grisáceo muy característico que hemos podido documentar en el resto de la alcazaba. Con la obra se buscaría ganar espacio útil para las tropas, convirtiendo la antigua entrada en una estancia y abriendo una nueva puerta, apta para el acceso de carros, en el CE 15, contiguo a la torre-puerta (Martín Civantos y Raya 2009). En este momento, el aspecto exterior del CE 14 sería ya el de una torre maciza, sin acceso desde el exterior, y la memoria de la antigua puerta se perderá con el tiempo.

Por último, en época contemporánea (IV) se acometieron las obras de restauración de la posguerra para convertir la alcazaba en parte del Seminario Menor. Se reconstruyeron pretiles y merlaturas y la parte superior de la E26, donde se abrirá el nuevo acceso a su terraza almenada. Desde ese momento se le aplicaron diversos parches de cemento. Se tapió además el vano interior, que fue de nuevo reabierto durante la intervención de 2005.

Podemos concluir, por tanto, que la torre-puerta de la alcazaba de Guadix es una interesante muestra de la evolución general del conjunto de la fortaleza: su creación en época zirí en el siglo XI; su monumentalización en época almohade o inicios de la nazarí, cuando el espacio interior de la fortificación se jerarquiza y se crea una estructura palatina; su abandono en época moderna; el uso como cuartel por las tropas francesas y la restauración de la segunda mitad del siglo XX. La transformación del acceso directo flanqueado por dos torres a una falsa torre-puerta una vez añadida la buhedera resulta 


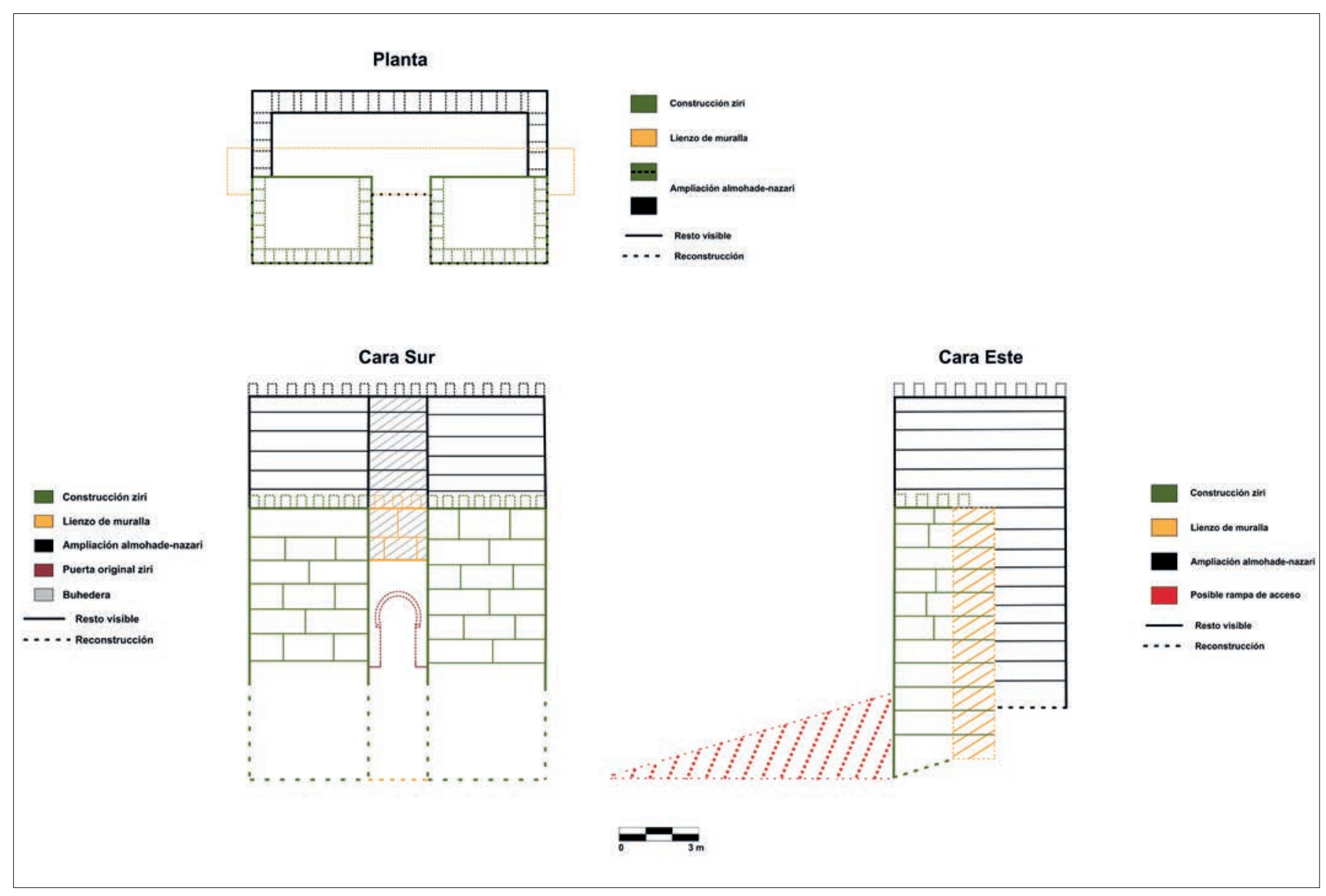

Figura 36. Propuesta esquemática de evolución de la torre-puerta en época medieval.

especialmente interesante. No tenemos constancia de otros ejemplos de una cronología similar en al-Ándalus en los que se produzca una adaptación de una puerta anterior hacia una falsa torre-puerta. La secuencia contrapone además dos técnicas constructivas vinculadas con dos momentos distintos, el tapial de calicanto zirí y el calicostrado almohade o nazarí. Estos poderes los emplearon en sus obras con el objetivo de hacer patente a través de la materialidad su dominio en el territorio y su recuerdo todavía pervive.

A pesar de la importancia patrimonial de la torrepuerta, la situación de degradación en la que se encuentra es preocupante y requiere, entre otras actuaciones, de la adopción urgente de medidas adecuadas de índole técnica, administrativa y económica para su correcta protección y conservación. Desde que en el 2005 se realizara una primera intervención arqueológica de apoyo y el apuntalamiento provisional del muro de la buhedera no se ha hecho nada más. Esperamos que nuestra contribución sea útil no solo para conocer mejor el proceso histórico de formación de la alcazaba y de este acceso, sino también para ofrecer información arqueológica, constructiva y gráfica que permita su restauración. Con el presente trabajo no solo aportamos la reconstrucción de la secuencia, análisis sobre técnicas y materiales constructivos y datos sobre el origen de alguna de las patologías, también una detallada y precisa documentación gráfica que es fundamental para cualquier intervención. Los nuevos sistemas de registro gráfico tridimensional a partir fotogrametría multimagen y su posterior gestión mediante sistemas CAD o GIS permiten un considerable aumento de la calidad gráfica y precisión métrica, reduciendo la subjetividad y facilitando la obtención de una documentación cada vez más completa y exhaustiva. Esto posibilita la planificación de un proyecto de conservación y restauración a partir del estudio que arqueológico que impida la desaparición del valor patrimonial e histórico del edificio. 


\section{FUENTES PRIMARIAS}

'Abd Allāh. 2005: Mudakkirat al-amir 'Abd Allah, ajir muluk Banu Ziri bi-Garnata (469-483). Traducido al castellano en É. Lévi-Provençal y E. García Gómez (eds.), El siglo XI en $1^{a}$ persona. Las «Memorias» de 'Abd Allah, último rey zirí de Granada, destronado por los almorávides (1090). Alianza, Madrid.

Huici Miranda, A. (trad.) 1951: Al-Hulal al-Mawšiyya. Crónica árabe de las dinastías almorávide, almohade y benimerín. Editora Marroquí, Tetuán.

Ibn al Jatib. 1976: Al-ihāta fì ajbār Garnāta. Maktaba al-Janŷî, El Cairo. [Abd Allah 'Inān (ed.)].

Ibn al Jatib. 1997: Mi'yār al-Ijtiyār fì dikr al-Ma hid wa-l-diyār. Instituto Universitario de la investigación científica de Marruecos, Rabat. [M. K. Chabbana (ed.)].

Ibn Hayyan. 1954: Al-Muqtabas III. Traducido al castellano en J. E. Guraieb: "«Al-Muqtabis» de Ibn Hayyan", Cuadernos de Historia de España, XXIXXII, pp. 329-344.

Martín Civantos, J. M. 2010a: Informe preliminar de la intervención arqueológica puntual de apoyo a la propuesta de parque arqueológico en la alcazaba de Guadix (Granada). Informe inédito. Junta de Andalucía: Consejería de Cultura, Granada

Sánchez Martínez, M. 1976: "La cora de Ilbira (Granada y Almería) en los siglos X y XI, según Al-'Udri (1003-1085)”, Cuadernos de Historia del Islam, 7, pp. 5-82. [Traducción parcial al castellano de Al Udri: Nusūs 'an al-Andalus min kitāb tarșī’ al-akhbār wa-tanwī' al-āthār wa-l-bustān fi gharā'ib al-buldān wa-l-masālik ilā jamī' al-mamālik].

Soler García, G. J. 2013: Documentación gráfica del patrimonio mediante el uso de nuevas tecnologías. Proyecto Monográfico de Investigación. Universidad de Granada, Escuela Técnica Superior de Ingeniería de Edificación.

Ubieto Arteta, A. (ed.) 1955: Crónica de los Estados peninsulares. Universidad de Granada, Granada.

\section{BIBLIOGRAFÍA}

Benavides López, J. A. 2017: Nuevas tecnologías aplicadas a la documentación gráfica del patrimonio. La alcazaba de Guadix y el castillo de Píñar Universidad de Granada, Granada.

Benavides López, J. A., Aranda Jiménez, G., Sánchez Romero, M., Alarcón García, E., Fernández Martín, S., Lozano Medina, A. y Esquivel Guerrero, J. A. 2016: "3D modelling in archaeology: the application of Structure from Motion methods to the study of the megalithic necropolis of Panoria (Granada, Spain)", Journal of Archaeological Science: Reports, 10, pp. 495-506.

Brogiolo, G. P. 1988: Archeologia dell'edilizia storica. Edizioni New Press, Como.

García Porras, A. 2015: "Nasrid Frontier Frontesses and Manifestations of Power: The Alcazaba of Moclín Castle as Revealed by Recent Archaeological Research", en A. Fábregas García y F. Sabaté (eds.), Power and rural communities in al-Andalus, pp. 113-133. Brepols, Turnhout.

García Porras, A. 2016: "La implantación del poder en el medio rural nazarí. Sus manifestaciones materiales en las fortalezas fronterizas granadinas", en A. Echevarría Arsuaga y A. Fábregas García (eds.), De la alquería a la aljama, pp. 223-259. UNED, Madrid.

Gómez-Moreno Calera, J. M. 2009: Arquitectura mudéjar en la comarca de Guadix. Centro de Iniciativas Turísticas de la Comarca de Guadix, Guadix.

Lanjouw, T. 2016: "Discussing the obvious or defending the contested: why are we still discussing the 'scientific value' of 3D applications in archaeology?”, en H. Kamermans,W. de Neef, C. Piccoli, A. G. Posluschny y R. Scopigno (eds.), The three dimensions of archaeology. Proceedings of the XVII UISPP World Congress (1-7 September 2014, Burgos, Spain), vol. 7, pp. 1-11. Archaeopress Archaeology, Oxford.

Lowe, D. 1999: "Object recognition from local scale-invariant features", en The Proceedings of the Seventh IEEE International Conference on Computer Vision, vol. 2, pp. 1150-1157. IEEE Computer Society, Washington.
Malpica Cuello, A. 2009: "Castillos, alquerías y ciudades en al-Andalus. Un debate partiendo del análisis arqueológico", en Á. L. Molina Molina y J. Eiroa Rodriguez (eds.), El castillo medieval en tiempos de Alfonso $\mathrm{X}$ el Sabio, pp. 99-120. Universidad de Murcia, Murcia.

Malpica Cuello, A., Mattei, L., Martín Civantos, J. M. a , González Escudero, Á. y Ruiz Jiménez, A. 2015: "Periodización y fases a partir del análisis histórico arqueológico de la Madraza", en A. Malpica Cuello y L. Mattei (coords.), La madraza de Yusuf I y la ciudad de Granada: análisis arqueológico, pp. 229-333. Universidad de Granada, Granada.

Martín Civantos, J. M. 2007: Poblamiento y territorio medieval en el Zenete. Editorial de Granada, Granada.

Martín Civantos, J. M. 2008: "El tapial de cal y cantos: una técnica constructiva de Época Zirí (s. XI)”, en N. Ferreira Bicho (ed.), A ocupaçao islâmica da Península Ibérica: actas do IV congresso de arqueologia peninsular (Faro, 14 a 19 de Setembro de 2004), pp. 125-138. Universidade do Algarve, Faro.

Martín Civantos, J. M. 2009: "Sistematización y datación de las técnicas constructivas andalusíes en el territorio de Ilbira-Granada: el caso del tapial de cal y cantos", en Á. Suárez Márquez (ed.), Construir en al-Ándalus, vol. 2, pp. 205-231. Consejería de Cultura, Almería.

Martín Civantos, J. M. 2010b: "La formación de la tierra de Guadix (Granada)", en A. Malpica, R. Peinado y A. Fábregas (coords), Historia de Andalucía. VII coloquio. Universidad de Granada, Granada.

Martín Civantos, J. M. y Raya García, S. 2009: "La alcazaba de Guadix: de fortaleza andalusí a cuartel militar napoleónico", Boletín del Centro de Estudios "Pedro Suárez", 21, pp. 283-296.

Martín García, M. 2009: "La construcción del tapial calicastrado en época nazarí”, $V$ Convención técnica y tecnológica de la arquitectura técnica, pp. 1-11. Colegio Oficial de Aparajedores y Arquitectos Técnicos de Albacete, Albacete.

Martín García, M. y Martín Civantos, J. M. 2009: "Técnicas y tipologías constructivas de las fortificaciones medievales de la Axarquía almeriense", en S. Huerta, R. Marín, R. Soler y A. Zaragozá (eds.), Actas del Sexto Congreso Nacional de Historia de la Construcción, vol. 2, pp. 815-824. Instituto Juan de Herrera, Madrid.

Parenti, R. 1988: "Le tecniche di documentazione per una lettura stratigrafica dell'elevato", en R. Francovich y R. Parenti (eds.), Archeologia e restauro dei monumenti, pp. 249-279. All'Insegna del Giglio, Florencia.

Parenti, R. 1995: "Historia, importancia y aplicaciones del método de lectura de paramentos", Informes de la Construcción, 46, 435, pp. 19-29.

Parenti, R. 1996: "Individualización de las unidades estratigráficas murarias", en L. Caballero Zoreda y C. Escribano Velasco (eds.), Arqueología de la arquitectura: el método arqueológico aplicado al proceso de estudio y de intervención en edificios históricos, pp. 75-85. Junta de Castilla y León, Salamanca.

Pavón Maldonado, B. 1999: Tratado de Arquitectura hispanomusulmana. Ciudades y fortalezas. Vol. II. CSIC, Madrid.

Pereira Uzal, J. M. 2016: "3D modelling in cultural heritage using structure from motion techniques", Ph investigación, 6, pp. 49-60.

Ramírez Burgos, M. 2017: El sistema de información geográfica del patrimonio histórico-artístico y arqueológico de la ciudad de Guadix (Granada). Universidad de Granada, Granada.

Raya de Cárdenas, M. 1987: "Excavaciones arqueológicas en la alcazaba de Guadix (Granada)", Anuario Arqueológico de Andalucía 1986, Actividades de Urgencia, vol. III, pp. 134-137. Junta de Andalucía, Consejería de Cultura, Sevilla.

Rouco Collazo, J. 2017: "La alcazaba y la ciudad de Guadix (Granada). Perspectivas desde la Arqueología de la Arquitectura", en A. Millán da Costa, A. Aguiar Andrade y C. Tente (eds.), O papel das pequenas cidades na construção da Europa Medieval, pp. 177-196. Instituto de Estudios Medievais, Lisboa.

Salvador Ventura, F. 1998: "El poblamiento en la Provincia de Granada durante los siglos VI y VII", Antigüedad Cristiana, V, pp. 339-357.

Sarr Marroco, B. 2011: "Algunas consideraciones sobre la evolución del Guadix islámico a la luz de las fuentes árabes y del registro arqueológico", Boletín del Centro de Estudios "Pedro Suárez”, 24, pp. 39-54. 
Sarr Marroco, B. y Mattei, L. 2011: "De hisn a madina. La evolución del urbanismo en el surco intrabético: Guadix, Loja y otros espacios menores. Un estado de la cuestión", Espacio, Tiempo y Forma. Serie III, Historia medieval, 24, pp. 387-414.

Sarr Marroco, B. y Reyes Martínez, E. 2006: “Intervención arqueológica de apoyo a la restauración del torreón sureste de la Alcazaba de Guadix (Granada, 2005)", Arqueología y Territorio Medieval, 13.2, pp. 127-144.

Snavely, N. 2010: Bundler: Structure from Motion (SFM) for unordered image collections. Retrieved from: phototour.cs.washington.edu/bundler/
Tabales Rodríguez, M. Á. 2002: Sistema de análisis arqueológico de edificios históricos. Universidad de Sevilla, Sevilla.

Trillo San José, C. 2007: “Agentes del Estado y mezquitas en el reino nazarí, Historia, Instituciones, Documentos, 34, pp. 279-291.

Van Leusen, M. y Van Gessel, S. 2016: "Towards 3D GIS. Notes from the 2012 CAA-NL/DE chapter session 'from 2.5 to 3 spatial dimensions", en H. Kamermans, W. de Neef, C. Piccoli, A. G. Posluschny y R. Scopigno (eds.), The three dimensions of archaeology. Proceedings of the XVII UISPP World Congress (1-7 September 2014, Burgos, Spain), vol. 7, pp. 33-37. Archaeopress Archaeology, Oxford. 